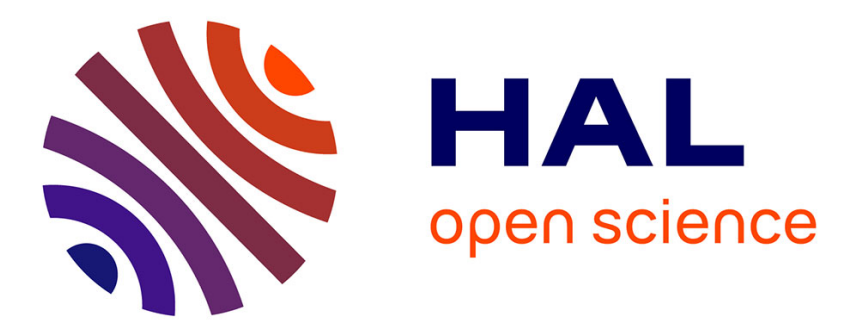

\title{
Portents in Early Imperial China: Observational Patterns from the "Spring and Autumn" Weft Profoundly Immersed Herptile (Qiantan ba )
}

\author{
Grégoire Espesset
}

\section{- To cite this version:}

Grégoire Espesset. Portents in Early Imperial China: Observational Patterns from the "Spring and Autumn" Weft Profoundly Immersed Herptile (Qiantan ba ). International Journal of Divination and Prognostication, 2019, 1 (2), pp.251-287. 10.1163/25899201-12340010 . hal-03466479

\author{
HAL Id: hal-03466479 \\ https://hal.science/hal-03466479
}

Submitted on 7 Dec 2021

HAL is a multi-disciplinary open access archive for the deposit and dissemination of scientific research documents, whether they are published or not. The documents may come from teaching and research institutions in France or abroad, or from public or private research centers.
L'archive ouverte pluridisciplinaire HAL, est destinée au dépôt et à la diffusion de documents scientifiques de niveau recherche, publiés ou non, émanant des établissements d'enseignement et de recherche français ou étrangers, des laboratoires publics ou privés. 


\title{
Portents in Early Imperial China: Observational Patterns from the "Spring and Autumn" Weft Profoundly Immersed Herptile (Qiantan ba 潛潭巴)
}

\author{
Grégoire Espesset* \\ Centre national de la recherche scientifique, Paris, France \\ espessetgregoire@gmail.com
}

\begin{abstract}
Still neglected by modern research, the "Weft" (or "Apocrypha") contain a wealth of unexploited data relevant to Chinese history in Late Antiquity and the Early Middle Ages. Sometimes ascribed to Confucius, these texts, whose Chinese name (wei 緯) denotes the crosswise threads of woven fabric, have long been perceived as arcane supplements to the "Classics," called jing 經, the lengthwise threads. Repeatedly prohibited and destroyed, they survive mainly as citations today. This paper focuses on one of them, anonymous, undated, and fragmentary, titled Qiantan ba 潛潭巴. Most of its remnants present extrapolations derived from observed phenomena interpreted as signs. By comparing the observed patterns to the typology of portents in the official monographs on celestial phenomena and the Five Agents of the era, the paper sheds light on the logic at work in the interpretative process.
\end{abstract}

\section{Keywords}

China - history - Late Antiquity (1st-2nd cent.) to Early Middle Ages (3rd-6th cent.) ancient science - portents - wei 緯 (Weft) - Qiantan ba 潛潭巴

This essay is based on an experiment that consists in bringing together two groups of sources more or less contemporary: on the one hand, fragments from

* Primary research for this paper was funded by a visiting fellowship from the Internationales Kolleg für Geisteswissenschaftliche Forschung (IKGF), Erlangen, November 2012-October 2013. An earlier draft was presented to the workshop on "Divination and the Strange in Preand Early Modern East Asia and Europe," IKG F, Erlangen, 27-28 October 2015.

(C) KONINKLIJKE BRILL NV, LEIDEN, 2020 | DOI:10.1163/25899201-12340010 
a "Weft" (wei 緯) book; on the other hand, the "monographs" or "treatises" literally "documents" (shu 書) or "memoir" (zhi 志) in Chinese, a difference assumed to be formal-on portents from the official historiography of the Han era (late third century BCE to early third century CE). From the first group I extract a series of "observational patterns," in other words, phenomena that were regarded as "signs" to be interpreted in order to acquire knowledge otherwise out of reach. ${ }^{1}$ Then I process these observational patterns typologically and statistically, according to the interpretative framework provided by the second group. The aim of the experiment is to shed light on the logic underlying these "patterns" so as to improve our understanding of how literate segments of early imperial Chinese society perceived some observed phenomena as "signs" to be interpreted. The relevant material is strictly textual.

Beyond the experiment proper, this paper may also work as a case study showing how Weft literature may be approached, despite the inherent difficulties of a fragmentary corpus of mostly decontextualized, often badly transmitted remnants. Before moving on to the core of the analysis, I shall first give a brief overview of the Weft corpus, and then offer elements of a critical discussion of the title of the book under consideration, of its authorship and literary history, and of its present textual condition. \\ The Weft Corpus: a Short Introduction}

Weft books are also known as "Confucian Apocrypha," "Han Apocrypha," or simply "Apocrypha" in Western Sinology.2 They bloomed around the turn of

1 The experiment does not deal with the knowledge extrapolated from these "observational patterns." I made a primary analysis of this knowledge for an (unpublished) IKGF Lecture in Erlangen, 22 October 2013, under the title "Knowledge and Foreknowledge Extrapolation in First-Second Century China: Remnants of the Spring \& Autumn Weft Profundity and Remoteness."

2 Historical introductions to the Weft corpus in Western languages include Max Kaltenmark, "Les Tch'an-wei," Han-Hiue: Bulletin du Centre d'études sinologiques de Pékin 2, no. 4 (1949): 363-373; Tjan Tjoe Som, Po Hu T'ung: The Comprehensive Discussions in the White Tiger Hall, vol. 1, Introduction; Translation of Chapters I, II, XVIII, XL; Notes. A Contribution to the History of Classical Studies in the Han Period (Leiden: E.J. Brill, 1949), 100-106; Jack L. Dull, "A Historical Introduction to the Apocryphal (Ch'an-wei) Texts of the Han Dynasty," PhD diss., University of Washington (Seattle, 1966); and, more recently, Licia Di Giacinto, The Chenwei Riddle: Time, Stars, and Heroes in the Apocrypha (Gossenberg: Ostasien Verlag, 2013), 1-12. On the latter, see my review in T'oung Pao 100 (2014): 505-511. For discussions of terminology, see Hans van Ess, "The Apocryphal Texts (ch'en-wei) of the Han Dynasty and the Old Text/New Text Controversy," T'oung Pao 85 (1999): 30-36; Zongli Lu, Power of the Words: Chen Prophecy in Chinese Politics, AD 265-618 (Bern: Peter Lang, 2003), 24-30; Grégoire Espesset, 
the first century $\mathrm{CE}$, in a context of political competition for supreme power. They were given an official edition upon imperial order in $56 \mathrm{CE}$. Though related by name, and supposedly by contents, to the "Confucian" Classics (jing 經), whose commentaries indeed often cite them, they had their own agenda, primarily concerned with the cosmic mechanisms underlying sovereign legitimacy and social order. As potential propaganda tools of would-be emperors, they were soon targeted by repeated prohibition, primarily directed against their private ownership. ${ }^{3}$ As a result, by Song 宋 times (96o-1279) most were lost while some partly survived in the form of citations in a variety of sources. ${ }^{4}$ In the nineteenth and twentieth centuries, Chinese scholars compiled these remnants into a number of compendia. ${ }^{5}$ One of these compendia, the Weft [Materials] Garnered (Weijun 緯擖) by Qiao Songnian 喬松年 (18151875), published posthumously in 1877 , was used as basic text by two Japanese scholars, Yasui Kōzan 安居香山 (1921-1989) and Nakamura Shōhachi 中村 璋八 (1926-2015), to produce the first-ever critical edition of the corpus. ${ }^{6}$ In that critical edition, Weft materials were classified into eleven classes, and

"Epiphanies of Sovereignty and the Rite of Jade Disc Immersion in Weft Narratives," Early China 37 (2014): 395-401; Zhao Lu, In Pursuit of the Great Peace: Han Dynasty Classicism and the Making of Early Medieval Literati Culture (Albany: State University of New York Press, 2019), Appendix 6, 213-215.

3 Weft proscriptions are documented for a period spanning eleven centuries. Dull, "A Historical Introduction to the Apocryphal (Ch'an-wei) Texts of the Han Dynasty," 405-406, dated the earliest proscription to before 217, "within the last five years" of the Later Han 後漢 $\left(25^{-220}\right)$ dynasty. Zeng Dexiong 曾德雄, “Chenwei de jinjue yu jiyi” 讖緯的禁絕與輯佚, Yunmeng xuekan 32 , no. 5 (2011): $58-66$, lists over a dozen records of governmental proscriptions up to 1373 .

4 The "Memoir on the Arts and Letters" ("Yiwen zhi” 㙯文志) in the mid-fourteenth century History of the Song (1345) acknowledges the existence of a single Weft type, that of the $Y i$ 易 (Changes), and lists four titles; see Song shi 宋史 (Beijing: Zhonghua shuju, 1985), 22.5041. This type is included in a broader "Changes category" ("Yi lei" 易類), on which see Bent Nielsen, A Companion to Yi Jing Numerology and Cosmology: Chinese Studies of Images and Numbers from Han 漢 (202 BCE-220 CE) to Song 宋 (960-1279CE) (London: RoutledgeCurzon, 2003), 306.

5 See Yasui Kōzan 安居香山 and Nakamura Shōhachi 中村璋八, Isho no kisoteki kenkyū 緯書 の基礎的研究 (Tokyo: Kan-Gi bunka kenkyūkai, 1966), 326-355.

6 Originally published as the handwritten and mimeographed, six-volume Isho shüsei 緯書 集成 (Tokyo: Kan-Gi bunka kenkyūkai, 1959-1964), this edition was reissued, expanded, corrected and typeset, as the Jüshü isho shūsei 重修緯書集成 (Tokyo: Meitoku, 1971-1992). The People's Press of Hebei (Shijiazhuang) published a three-volume Chinese version of the latter, with additional revisions, titled Weishu jicheng 緯書集成 (1994). An exception, Yasui and Nakamura used the Sibujiyao 四部集要 edition of the Eight Wefts of the Changes (Yiwei bazhong 易緯八種) as basic text for that particular category. 
the materials collected in each class were in turn arranged according to Weft book titles. ${ }^{7}$

In the Japanese critical edition, most Weft books bear a title prefixed by their parent class. The series of citations on which the present study focuses-one of the longest series in the critical edition-is attached to the title Qiantan $b a$ 潛潭巴 prefixed by the class “Chunqiu” 春秋 (“Spring and Autumn”). This class is named after the $\mathrm{Lu}$ 魯 state chronicle covering its twelve ducal reigns from 722 to 481 BCE. ${ }^{8}$

It is notoriously difficult to make sense of the titles of most Weft books. Tjan Tjoe Som 曾珠森 (1903-1969), referring to a remark by Gu Jiegang 顧頡剛 (1893-1980), already noted that "the names of the books are very peculiar and hardly intelligible."9 The Chunqiu qiantan ba 春秋潛潭巴 does not contradict this statement. Qian 潛 means "to lie at the bottom of water," thence "to hide," and "secret" or "deep" when adjectival. Tan 潭 means "deep water," "a pond" or "a pool," and "deep" also when adjectival. $B a$ 巴 is mostly known as a place name corresponding to eastern Sichuan province; otherwise, it is usually understood as denoting an unidentified species of large snakes, sometimes rendered as "pythons" in English, ${ }^{10}$ and it means "sinuous" when adjectival.

Dull rendered the title as "The Handle for [Grasping] the Hidden and Profound" and Di Giacinto, as "The Annals: Snake Immersed in the Pool." Both renditions have their merit and limitations. Dull's assumption that " $b a]$ 巴 has the meaning of [ba] 把" is not implausible, but remains conjectural. ${ }^{11}$

These classes and the titles therein are, in descending quantitative order: "River Chart" (“He tu” 河圖), 43 titles; "Spring and Autumn" (“Chunqiu” 春秋), 29; “Changes" (“Yi” 易), 24; “Accurate Observations" (“Zhonghou” 中候), 21; “Luo Writing” (“Luo shu” 洛書), 15; “Classic of Filial Piety” (“Xiaojing” 孝經), 15; “Analects” (“Lunyu” 論語), 9; “Documents” (“Shu” 書), 8; “Rites” (“Li” 禮), 4; “Poetry” (“Shi” 詩), 4; and “Music” (“Yue” 樂), 4. The total number of listed titles is 176 ; more if variants titles are to be counted separately.

See Anne Cheng, "Ch'un ch'iu, Kung yang, Ku liang and Tso chuan," in Early Chinese Texts: A Bibliographical Guide, ed. Michael Loewe (Berkeley: Society for the Study of Early China, and Institute of East Asian Studies, University of California, Berkeley, 1993), 67-76.

9 See Tjan, Po Hu T’ung, 1:102 and n.346. Tjan cited Gu Jiegang's Han dai xueshu shilüe 漢代 學術史略 (Shanghai: Zhongguo wenhua fuwushe, 1936).

10 For $b a$ depicted as a mythical giant snake, see Richard E. Strassberg, A Chinese Bestiary: Strange Creatures from the Guideways Through Mountains and Seas (Berkeley: University of California Press, 2002), 19o, Plate LV, item 267. Note that the picture on p. 69 (Fig. 24) in Strassberg's book dates to the early or mid-seventeenth century.

11 Dull, "A Historical Introduction to the Apocryphal (Ch'an-wei) Texts of the Han Dynasty," 417, n.5. 
Di Giacinto's rendition is only justified by the claim that her "rough translations of the chenwei titles are based on the contents of the [texts] and the notes of Sun Jue [孫款] in [the Ancient Arcane Writings (Gu weishu 古微書)]."12 Indeed, in late Ming 明 (1368-1644) times, that scholar of unknown dates discussed the meaning of this title as follows:

潛潭者, 水之沈深也, 巴又水之屈曲也. 蜀江學巴字而流, 蓋其遠也. 撰名 若此, 誨之甚.

"Lying at the bottom of deep water" evokes the depth of waterways and "sinuous," the twists and turns of waterways. The Shu River ${ }^{13}$ imitates the word "sinuous" as it flows, because of its distance. To compose a title like that is bizarre to the extreme. ${ }^{14}$

Later on, another collector of Weft remnants, Zhao Zaihan 趙在翰 (dates unknown), also discussed the title in the "descriptive notes" (xulu 叙録) appended to his Seven [Categories of] Weft [Writings] (Qiwei 七緯). The penultimate "note" enumerates thirteen titles of "Spring and Autumn" Weft books. It includes the following passage:

其機難測, 其理難明, 幽則潛也, 曲如巴也, 潛潭巴又次之.

Its mechanisms difficult to fathom and its principles difficult to understand, obscure hence deep, twisted as if sinuous, next again comes the Qiantan ba. ${ }^{15}$

In sum, to both Sun Jue and Zhao Zaihan, the title would allude to the profound and convoluted nature of the "Spring and Autumn" chronicle. My own hypothesis is that the title alludes to Qian 乾 (Pure Yang), the first of the sixtyfour hexagrams of the Book of Changes (Yijing 易經). The explanation of this

12 Di Giacinto, The Chenwei Riddle, 86 and 278, n.35.

13 Ancient name of the Min River 峔江 and of the part of the upper Yangtze River that it joins up with in today's central Sichuan province. Shu 蜀 is the name of an ancient kingdom based in an area roughly corresponding to the Chengdu 成都 plain. Sun Jue may have been inspired by the fact that $\mathrm{Ba}$ is a common correlative of Shu, for instance in the alternative designation for Sichuan "Ba-Shu" 巴蜀.

14 Sun Jue, Gu weishu, in Siku quanshu, 11.1a.

15 Zhong Zhaopeng 鍾肇鵬 and Xiao Wenyu 蕭文郁, Qiwei 七緯 (Beijing: Zhonghua shuju, 2012), 38.979. Chapter 38 is an 1809 addition to the 37 -chapter edition published in 1804 . In the excerpt cited, $q i$ 其 ("its" twice in my translation) may refer to the Qiantan ba itself, or to the "Spring and Autumn" chronicle as parent Classic of the whole series, or even to the Way of Heaven (tiandao 天道) mentioned in a preceding passage. 
hexagram's Initial Nine (chujiu 初九) - the first line at the bottom of a hexagram when that line is Yang (unbroken)—reads:

潛龍, 勿用.

Dragon lying at bottom of water; do not take action. ${ }^{16}$

The traditional interpretation of Yang (the Yang line) in a lower position exalts “[to have] Virtue yet being hidden," de eryinzhe ye 德而隱者也. ${ }^{17}$ Citations from other Weft books report that the "cerulean sage" (xuansheng 玄聖) Confucius was himself of draconic nature, born from a woman and the essence of the Black Emperor (heidi 黑帝) or Black Dragon (heilong 黑龍), the cosmic agency corresponding to the agent Water and the North. ${ }^{18}$ This is related to the theory of Confucius as Uncrowned King (suwang 素王, literally "unadorned king"), "one who possesses the true qualities of a king though they are not displayed," as Loewe wrote..$^{19}$ Designed to support the legitimacy of the Han house, this theory held that the purpose of Confucius had been not to rule in effect, but to compose the "Spring and Autumn" as an ethical and governmental roadmap for the Han (agent Fire), the legitimate successors of the Zhou (agent Wood). ${ }^{20}$

The dragon (long 龍) and the animal called $b a$ must have been two different beasts unless the latter signifier referred to the former animal in a particular context or lexicon, or in some dialectal usage. And yet the Explanation of

16 Zhou Yi zhengyi 周易正義 (Correct Meaning of the Changes of the Zhou), ed. Wang Bi 王貆 (226-249), in Shisan jing zhushu 十三經注疏, ed. Ruan Yuan 阮元 (1764-1849) (Beijing: Zhonghua shuju, 1980), 1.1a. Cf. Richard J. Lynn, The Classic of Changes: A New Translation of the I Ching as Interpreted by Wang Bi (New York: Columbia University Press, 1994), 132: "A submerged dragon does not act."

17 Zhou Yi zhengyi, in Shisan jing zhushu, 1.1a-b. Cf. Lynn, The Classic of Changes, 132.

18 See Tjan, Po Hu T'ung, 1:112-113; Dull, "A Historical Introduction to the Apocryphal (Ch'an-wei) Texts of the Han Dynasty," 517, 519, and 524; Zhao, In Pursuit of the Great Peace, $83-84$. The color of the northern sky, xuan 玄 is metonymic of heaven as huang 黃 (yellow) is of earth.

19 Michael Loewe, Dong Zhongshu, a "Confucian" Heritage and the Chunqiu Fanlu (Leiden: Brill, 2011), 173 .

20 Michael Nylan, The Five "Confucian" Classics (New Haven: Yale University Press, 2001), 306. See also Michael Nylan, "Kongzi, the Uncrowned King," in Lives of Confucius: Civilization's Greatest Sage through the Ages, by Michael Nylan and Thomas Wilson (New York: Doubleday, 2010), 67-100; Alan K.L. Chan, "From Uncrowned King to the Sage of Profound Greatness: Confucius and the Analects in Early Medieval China," in A Concise Companion to Confucius, ed. Paul R. Goldin (Hoboken: John Wiley and Sons, 2017), 249267. For the image of Confucius as Uncrowned King in Weft literature, see Tjan, $\mathrm{Po} H u$ T'ung, 1:112-117; Dull, "A Historical Introduction," 516-527; Zeng Dexiong, "Chenwei zhong de Kongzi” 讖緯中的孔子, Renwen zazhi 人文雜誌, 2006 no. 1,: 98-105; Zhao, In Pursuit of the Great Peace, $85^{-89}$. 
Graphs and Analysis of Characters (Shuowen jiezi 說文解字), roughly contemporaneous (circa 100 CE) with our text, describes both as being chong 蟲, that is, legged "animals" today variously categorized as invertebrates, reptiles, and amphibians, among others. ${ }^{21}$ This challenges the received interpretation of $b a$ as an ophidian and would rather point to a legged animal of the "herptile" type. ${ }^{22}$ Moreover, the Explanation of Graphs and Analysis of Characters characterizes dragons as, among other things, "ascending to the heavens on the vernal equinox and lying at the bottom of abysses on the autumnal equinox," and uses the same logogram qian 潛 to refer to the submersion. ${ }^{23}$

To sum up, I hypothesize that Qiantan ba alludes to the latent potential of Confucius as a shadow kingmaker and to the far-reaching profundity of the "Spring and Autumn" Classic as his work, and I suggest Profoundly Immersed Herptile as a tentative translation for this title.

\section{3}

\section{Authorship and Literary History}

Our text is cited once in the chapter on "Calamities and Alterations" "Zaibian" 災變) of the Comprehensive Discussions in the White Tiger [Pavilion] (Baihu tongyi 白虎通義 or Baihu tong 白虎通). ${ }^{24}$ The compilation of that work, derived from a conference held in $79 \mathrm{CE}$, is traditionally ascribed to Ban $\mathrm{Gu}$ 班固 (3292), but the received edition could date to the first half of the third century. ${ }^{25}$ It is also cited in a "response" to the Throne (dui 對) composed by the famous scholar Zhang Heng 張衡 (78-139), a statesman and polymath, soon after an earthquake shook the dynastic capital Luoyang 洛陽 (in modern Henan) in $133 .{ }^{26}$ In 177 and 178 , two more responses to the Throne by yet another famous

21 Shuowen jiezi 說文解字, by Xu Shen 許慎 (ca. 58-ca. 147) (Beijing: Zhonghua shuju, 1963), 245b (long 龍), 284a (chong 蟲), and 309a (ba 巴). For the date of that source, see William G. Boltz, "Shuo wen chieh tzu," in Early Chinese Texts, ed. Loewe, 429-442. The shifting contours of the animals described as chong throughout Chinese history are surveyed in Francine Fèvre, "Drôles de bestioles: Qu'est-ce qu'un Chong?," Anthropozoologica 18 (1993): $57-65$.

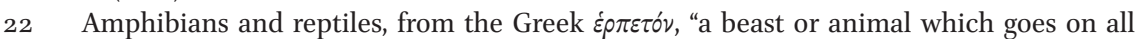
fours"; quoting Henry G. Liddell and Robert Scott, Greek-English Lexicon, 7th ed. (New York: Harper and Brothers, 1883), 581.

23 Shuowen jiezi, 245b: “春分而登天, 分秋而潛淵.”

24 See Baihu tong shuzheng 白虎通疏證, ed. Chen Li 陳立 (1809-1869) and Wu Zeyu 吳則 虞 (1913-1977) (Beijing: Zhonghua shuju, 1994), 6.268.

25 See Michael Loewe, "Pai hu t'ung," in Early Chinese Texts, ed. Loewe, 347-356.

26 Yet there is some doubt as to the genuineness of this citation. Firstly, in Yuan Hong's 袁宏 (328-378) Later Han Annals (Hou Han ji 後漢紀), Zhang's response contains no Qiantan ba citation; see Hou Han ji (Beijing: Zhonghua shuju, 2002), 18.512-514. Secondly, in his Complete Later Han Literature (Quan Hou Han wen 全後漢文), the Qing 清 
scholar, Cai Yong 蔡邑 (132-192), cite other passages from the Qiantan ba. ${ }^{27} \mathrm{In}$ sum, the Qiantan ba may have been in existence at the time of the White Tiger Pavilion conference, but the earliest safely dated occurrences of its title date to the second century CE.

Like most Weft books, there is no author name attached to the Qiantan ba. A late source, the Complete Collection of Illustrations and Writings Past and Present (Gujin tushu jicheng 古今圖書集成), edited by Chen Menglei 陳夢雷 (1650-1741), revised by Jiang Tingxi 蔣廷錫 (1669-1732) and printed in 1728, associates it once with the name of Jing Fang 京房 (77-37 BCE), a specialist of the Changes to whom three dozens of works have been traditionally ascribed. ${ }^{28}$ Indeed, the "Memoir on the Five Agents" ("Wuxing zhi") compiled by Ban Gu before $92 \mathrm{CE}$ for his Han Documents (Han shu 漢書) quotes a passage from Jing Fang's Changes Tradition (Yizhuan 易傳) that matches a citation of our text, variants notwithstanding. ${ }^{29}$

Some of the commentaries ( $z h u$ 注) attached to a few citations of our text are ascribed to a former student of the renowned scholar Zheng Xuan 鄭玄 (127-200), Song Jun 宋均, who became Academician (boshi 博士) under Wei 魏

dynasty (1644-1911) scholar and bibliophile Yan Kejun 嚴可均 (1762-1843) included an extended version of Zhang's response, titled "Policy Proposal in Response to [the Throne Concerning] the Earthquake in the Capital on the Second Year of the Yangjia [Era]” (“Yangjia er nian jingshi dizhen duice” 陽嘉二年京師地震對策); see Quan Hou Han wen (Beijing: Zhonghua shuju, 1995), 54.3b-4a. According to Yan's annotation, the Qiantan ba citation is an addition derived from a commentary to the "Memoir on the Five Agents” (“Wuxing zhi” 五行志) in Sima Biao's 司馬虎 (circa 240-circa 306) Supplement to the Han Documents (Xu Han shu 續漢書), a third-century history of the restored Han dynasty and one of the sources used by Fan Ye 范瞱 (398-445) to compile the received Later Han Documents (Hou Han shu 後漢書), completed in 445. Later on, this monograph was appended to Fan Ye's work by Liu Zhao 劉昭 (fl. 502-520), with Liu's commentary; see B.J. Mansvelt Beck, The Treatises of Later Han: Their Author, Sources, Contents and Place in Chinese Historiography (Leiden: Brill, 1990), 33. The Qiantan ba citation does appear in Hou Han shu (Beijing: Zhonghua shuju, 1965), 15.3311, yet immediately following Zhang Heng's response, not inside it. We cannot ascertain whether it originally belonged to Zhang Heng's response dated 133, or to Liu Zhao's early sixth-century commentary.

27 Hou Han shu, "Zhi" ("Memoirs"), 13.3274 and 17.3351-3352. Both citations appear in the "Memoir on the Five Agents" mentioned in the preceding note.

28 Gujin tushu jicheng (Beijing: Zhonghua shuju, 1985), "Celestial Matters Repertory" (“Lixiang huibian” 曆象彙編), "Division on Various Manifestations" ("Shuzheng dian” 庶徵典), “Section on Solar Abnormalities” (“Riyi bu” 日異部), 18.25b. On Jing Fang, see Nielsen, A Companion to Yi Jing Numerology and Cosmology, 129-132.

29 Han shu (Beijing: Zhonghua shuju, 1962), 27BA.140o. Cf. Jūshū isho shūsei 重修緯書集成, vol. 4: Shunjü 春秋, part 2 (Tokyo: Meitoku, 1992), 97, 4th dotted item. 
kingship (220-265) and died before $265 \cdot^{30}$ As to Zheng Xuan himself, he appears frequently in the Weft corpus as a commentator, but not in the case of the Qiantan ba. ${ }^{31}$

The earliest bibliographical mention of the Qiantan ba that I could find appears in the Later Han Documents commentary, completed in the early days of 677 by Li Xian 李賢 (651-684) of the Tang 唐 dynasty (618-907) ruling house and a group of scholars. In a note explaining the phrase "seven [categories of] Weft [writings]" (qiwei 七緯) and unfolding a list of 35 Weft book titles, our text ranks penultimate in the last category. ${ }^{32}$ The next mention appears in the mideleventh century list of works cited that opens an encyclopedia intended for Song Emperor Taizong 太宗 (r. 976-997), the Taiping [Xingguo Era] Imperial Digest (Taipingyulan 太平御覽), compiled under the direction of Li Fang 李昉 (925-996). "Chunqiu qiantan ba" is the ninety-eighth of 1,663 titles therein. ${ }^{33}$ The Imperial Digest cites the text two dozen times, including once (at least in the Sibu congkan 四部叢刊 edition) under the variant title Spring and Autumn Tradition: Profoundly Immersed Herptile (Chunqiu zhuan qiantan ba 春秋傳潛潭巴). ${ }^{34}$

Yet being cited does not imply existence and circulation as an independent book. And indeed, in early Qing times, the scholar and poet Zhu Yizun 朱彝尊 (1629-1709) marked the Qiantan ba as being "lost" ( $y i$ 佚) in his critical catalogue, the General Bibliography of the Classics (Jingyi kao 經義考), published in $1705{ }^{35}$ Qi Zhaonan 齊召南 (1703-1768) opened his postscript to the Gongyang 公羊 exegesis by stating that the thirteen "Spring and Autumn" Weft books

30 Li Meixun 李梅訓, “Song Jun shengping zhushu kaolun” 宋均生平著述考論, Shandong shifan daxue xuebao (renwen shehui kexue ban) 49, no. 5 (2004): 90-93.

31 The surviving Weft commentaries by Zheng Xuan are the object of a doctoral dissertation by Lü Kai 呂凱, published in 1982 and recently reissued, Zheng Xuan de chenwei xue 鄭玄 的讖緯學 (Taipei: Taiwan shangwu yinshuguan, 2011).

32 Hou Han shu, 82A.2721-2722, commentary. The 35 titles are classified under the headings "Changes" (6 titles), "Documents" (5), "Poetry" (3), "Rites" (3), "Music" (3), "Filial Piety" (2), and "Spring and Autumn" (13). The list is devoid of any authorship and book length information.

33 Taiping yulan, in Siku quanshu, "Jingshi tushu gangmu" 經史圖書綱目, 4a. According to John Winthrop Haeger, "The Significance of Confusion: The Origins of the T'ai-p'ing yü-lan," Journal of the American Oriental Society 88, no. 3 (1968): 405, this list is an eleventh-century retrospective compilation. The Taiping yulan actually cites over 2,500 different works, $70-80 \%$ of which are today lost.

34 Taiping yulan, in Sibu congkan, 157.9a. The Siku quanshu edition, 157.15b, omits the logogram zhuan 傳, which denotes prominent "Spring and Autumn" exegetic traditions such as the Zuo 左, Guliang 穀梁 and Gongyang 公羊. The character is marked as being an interpolation in the Hebei Education Press edition (1994), 495.

Zhu Yizhun, Jingyi kao, in Siku quanshu, 266.13b. 
whose titles were mentioned by scholars since Li Xian's commentary on the Later Han Documents had not been transmitted for a long time. ${ }^{36}$ What is at stake in both cases is the fate of the text as a physical book, regardless of the existence of citations and possibly fragments.

The status of the Qiantan ba as a long-lost book being thus established, the Compilation of Lost Writings from Mount Yuhan Studio (Yuhanshan fang ji yishu 玉函山房輯佚書), compiled by Ma Guohan 馬國翰 (1794-1857) but belatedly published, lists under the "Weft writings category" ("Weishu lei" 緯書類) a "Spring and Autumn Weft:Profoundly Immersed Herptile, in 1 volume" (Chunqiu wei qiantan ba yi juan 春秋緯潛潭巴一卷). ${ }^{37}$ In my understanding, this does not mean that the Qiantan $b a$ suddenly reappeared as a physical book in one volume, but rather that its collected citations then filled a single textual unit within modern collections. (The logogram juan 卷 can denote a part or a chapter as well as an independent volume.)

In the Japanese critical edition, the reconstructed Qiantan ba unfolds as a loosely organized series of 232 citations collected from a variety of sources. I henceforth call "item" (short for "textual item") each such citation. ${ }^{38}$ The figure 232 includes a number of duplication cases, some marked as such by the Japanese editors, some unnoticed. In their original format and context, all items are explicitly citations from either the "Qiantan $b a$ " or "Chunqiu qiantan $b a$ " in some cases. ${ }^{39}$ Some items might be misattributed citations from other Weft books, ${ }^{40}$ or, naturally, from non-Weft sources.

36 Qi Zhaonan, Chunqiu Gongyang zhuan zhushu kaozheng bayu 春秋公羊傳注疏考證 跋語 (Postscript to Textual Criticism of the Spring and Autumn Gongyang Tradition, with main and sub-commentary), in Siku quanshu, 1a: “其書不傳久矣.”

37 Yuhanshan fang ji yishu, in Siku quanshu, "Contents" ("Mu” 目), 22a. Wang Renjun 王仁俊 (1866-1913) faithfully reproduced that information in his extended edition, compiled from 1888 to 1894, of Ma's work, the Sequel to the Compilation of Lost Writings from Mount Yuhan Studio (Yuhanshan fang ji yishu xubian 玉函山房輯佚書續編) (Shanghai: Shanghai guji chubanshe, 1989), "Contents" ("Mu"), $7 \mathrm{~b}$.

38 "Qiantan ba," Jūshü isho shüsei, 4.2: 73-98 (2: 829-853 in the 1994 Chinese edition). Items will be referred to following their order in the Jüshū isho shüsei page layout, under the format page/item; for example, " $74 / 6$ " refers to the sixth item on page 74 of the indicated volume.

39 The single exception is item 84/4, originally cited from a "Spring and Autumn Weft," Chunqiu wei 春秋緯.

40 Throughout the critical edition, the Japanese editors have noted a number of items that, in primary sources, are given as citations from two (or more) different titles, sometimes involving different parent classes. None of the Qiantan ba items is thus marked. However, 
The Later Han date of the earliest mentions of the title cannot be generalized to all 232 items, since most of them were retrieved by the Japanese editors from nine collections dating to the Yuan 元 (1271-1368), Ming, and (mainly) Qing dynasties. The two principal sources are by far the Series from the Hall of Classical Studies (Hanxuetang congshu 漢學堂叢書), by Huang Shi 黄奇 (1809/10-1853), published in 1893 (216 items, or more than 93\% of our text); and Mister Huang's Examination of Lost Writings (Huang shi yishu kao 黄氏逸 書考), an earlier yet incomplete version of the former, published in 1937 (213 items; nearly 92\%). ${ }^{41}$ The Japanese editors collated each citation with two dozen earlier sources spanning about fifteen centuries and dating mostly to the Tang and Song dynasties. In this earlier group, the two principal sources are, by far, the Prognostication Book of the Kaiyuan [Era] of the Grand Tang (Da Tang Kaiyuan zhanjing 大唐開元占經), by Qutan Xida 矍昙悉達 (Gautama Siddha), in 120 chapters, dated to between 718 and 726 (144 items; about $62 \%) ;{ }^{42}$ and the anonymous Qinghe Commandery Edition of Weft Writings (Qinghe jun ben weishu 清河郡本緯書), a source widely used by Huang Shi (86 items; about $37 \%) .{ }^{43}$ The periods covered by the late collections of citations on the one hand, and by the earlier sources used to collate them on the other hand, do in part overlap (see the appended Tables I and II).

Given the fragmentary condition of the extant material, we have only a scant idea of the book's original literary structure. The Japanese editors evidently strived to group the items into series that more or less share themes or a syntactical pattern, then to organize these groupings into a more or less logical sequence, but only limited consistency was achieved. Some groupings bring together items only vaguely related to one another, while some items

elsewhere in the corpus, unnoticed cases of such conflicting ascriptions can be detected, which suggests that some Qiantan ba items might be concerned as well.

41 Both versions are compared by Nakamura Shōhachi, "Shiryō hen" 資料篇, in Yasui and Nakamura, Isho no kisoteki kenkyū, 471-475. For Huang Shi's dates, see Cao Shujie 曹書杰, “Huang Shi shengzu kao” 黄奇生卒考, Dongbei shida xuebao (zhexue shehui kexue ban), 1989 no. 6, 109-110.

42 For the date of that source, see Yasui Kōzan, "Dai Tō Kaigen senkyō ihonkō" 大唐開元占 經異本考, Tōkyō kyōiku daigaku bungakubu kiyō 東京教育大學文學部紀要 32 (1961): 1-2. The figure 144 includes an occurrence of “城邑宮殿怪占” (item 77/11), which is apparently a section title from the Kaiyuan zhanjing mistakenly entered as an independent source.

43 This probably Ming source was lost in China after the Taiping Rebellion (1850-1864); see Zhong Zhaopeng 鍾肇鵬, Chenwei lunlüe 讖緯論略 (Shenyang: Liaoning jiaoyu chubanshe, 1991), 253-254. It may have been a local edition or reissue of the collection, used by the Japanese editors, simply titled Weft Writings (Weishu 緯書), compiled by a Yang Qiaoyue 楊喬获 and collated by a Du Shifen 杜士芬 of the Ming era (dates of both unknown). Created in Han times, Qinghe commandery covered areas in present-day Hebei and Shandong provinces. 
dealing with the same topic have been scattered, resulting in undetected cases of duplication. My tentative analysis of the reconstructed sequence suggests that its general underlying ideology is consonant with the well-known Han belief in the interdependence of the cosmos, natural phenomena, and human deeds, combined into an all-encompassing network of action and reaction sometimes called "resonance" or "stimulus-response" in Western scholarship. It is well known that, probably since the earliest times of Chinese civilization, the cosmos and human political organization were considered consubstantial. ${ }^{44}$ Of special importance was the nightly observation of the starry sky as a window onto the universe and its mechanisms, above all their regularity or irregularity. 45 This explains the prominence in "traditional sciences," widely acknowledged today, of data pertaining to astronomy and the calendar. ${ }^{46}$ Though the Qiantan ba is in line with the "mantic arts" mastered by Jing Fang and other specialists, we must keep in mind that distinct interpretative traditions coexisted. ${ }^{47}$

\section{$5 \quad$ Item Morphology and the Implicative Function}

Regardless of the basic distinction between main text and commentary, the longest item in the reconstructed text (item 83/2) has 329 logograms and the ten shortest ones, five each only. Most items share the same basic morphology: "if $\mathrm{X}$, then $\mathrm{Y}$," where $\mathrm{X}$ is what Western logic calls a premise and $\mathrm{Y}$, a conclusion.

44 See, among others, John B. Henderson, "Chinese Cosmographical Thought: The High Intellectual Tradition," in The History of Cartography, vol. 2, bk. 2, Cartography in the Traditional East and Southeast Asian Societies, ed. J.B. Harley and David Woodward (Chicago: University of Chicago Press, 1994), 203-227; Nathan Sivin, "State, Cosmos, and the Body in the Last Three Centuries B.C.," Harvard Journal of Asiatic Studies 55 (1995): 5-37; Geoffrey Lloyd and Nathan Sivin, The Way and the Word: Science and Medicine in Early China and Greece (New Haven: Yale University Press, 2002), 214-226.

45 See, among others, Xiaochun Sun and Jacob Kistemaker, The Chinese Sky during the Han: Constellating Stars and Society (Leiden: Brill, 1997), 95-112; Lillian L. Tseng, Picturing Heaven in Early China (Cambridge, MA: Harvard University Asia Center, 2011); David W. Pankenier, Astrology and Cosmology in Early China: Conforming Earth to Heaven (Cambridge: Cambridge University Press, 2013).

46 Marc Kalinowski, general introduction to Divination et société dans la Chine médiévale: Étude des manuscrits de Dunhuang de la Bibliothèque nationale de France et de la British Library, ed. Marc Kalinowski (Paris: Bibliothèque nationale de France, 2003), 12.

47 See Aihe Wang, Cosmology and Political Culture in Early China (Cambridge: Cambridge University Press, 2000), 134-135; Michael Nylan, "Yin-Yang, Five Phases, and Qi," in China's Early Empires: A Re-Appraisal, ed. Michael Nylan and Michael Loewe (Cambridge: Cambridge University Press, 2010), 398-414. 
(Importantly, the reverse - "if Y, then $\mathrm{X}$ "- is not necessarily true.) In propositional logic, this "rule of detachment" is called "modus ponens" (or "modus ponende ponens," "the way that affirms by affirming"). According to the grammatical categories of European languages, this model is that of a "conditional sentence" of the "implicative" type. ${ }^{48}$ All items sharing this morphology constitute what I call the "implicative" genre. ${ }^{49}$ Its function is to provide data $(\mathrm{Y})$ somehow related to, or extrapolated from, an observational pattern (X). As an example, let us consider one of the ten shortest items:

(77/1) 地震: 下謀上.

(X) Earthquake: (Y) Inferiors conspire against superiors (or the emperor).

Here the "observational pattern" is the shaking of earth, the "extrapolated data" a conspiracy. From a retrospective, Western point of view, one of the problems to address is whether such items may be interpreted as "predictive" or not. Some items would seem not so much to announce forthcoming events as to make a target individual (the monarch within the Palace, cut off from the "real" empire, or an imperial contestant) or a target group (the imperial or consort clan, top government officials, feudatories) aware of a recent event or an already developing situation of which unmediated knowledge would otherwise be lacking. In a limited number of items, the logograms jiang 將 ("to be about to") and hou 後 ("afterwards") function as temporal markers clearly expressing that any extrapolated data $(\mathrm{Y})$ are subsequent to the observation (X). But, in the absence of such temporal markers and of context, drawing a clear line between knowledge and foreknowledge in the extrapolated data often proves difficult. Thus, in the example above, for a Western reader, the

48 Ancient Greek grammarians called the dependent clause (or condition) in such a sentence "protasis" and the main clause (or consequence) "apodosis." This has become the standard terminology in Assyriology; see Francesca Rochberg, " 'If P, then Q': Form and Reasoning in Babylonian Divination," in Divination and Interpretation of Signs in the Ancient World, ed. Amar Annus (Chicago: The Oriental Institute of the University of Chicago, 2010), 19-27.

49 The remainder of the items come under what I call the "explicative" genre, concerned with systematic correlations and semantics; the "admonitory" genre, which warns a usually specified audience of the effects of improper action; the "prescriptive" genre, which gives guidelines for proper action or reaction; and the "narrative" genre, which reports the deeds of prestigious, historical or mythical figures. Commentaries arguably constitute a sixth genre in its own right. Note that this typology is tentative, its sole purpose being to provide a heuristic tool. Probably no Weft book of which more than a few citations subsist can be classified under a single genre. 
past, present, or future tense might be implied, as well as a possibility: "inferiors conspired, or are conspiring, or will conspire, or might conspire, ${ }^{50}$ against superiors." We shall see further on whether the Chinese mind, about two millennia ago, faced comparable interpretative difficulties.

Longer items sometimes display a clearer diachronic structure, which suggests that foreknowledge (and the future tense) may be our default option for interpreting (and translating) all implicative items. Item 88/1 below, our second example, belongs to a cluster of twelve parallel items $(87 / 1-89 / 4)$ that share a more developed morphology and a detailed temporal structure and derive knowledge from some of the twenty-eight lunar Lodges (xiu 宿) and variations in the solar photosphere (both the punctuation of the item below and its translation are tentative):

(88/1) 東井主六月. 日色赤如䫅, 旬望以上, 十 (二) 月朔日日蝕, 四 [分] (方) 射主, 武將威兵, 後九十日, 國大亂. 其 (來) 六月, 天鳴地坼, 三公九 卿皆反, 各自立為君, 勝者稱王, 非天命也.

The Eastern Well ${ }^{51}$ rules over the sixth month. (X) [If] the color of the sun is red like crimson for more than a decade or a fortnight, $(\mathrm{Y})$ on the first day of the twelfth ${ }^{52}$ month [there will be] a solar eclipse; the four quadrants $^{53}$ [will] target the ruler, and a military high officer [will] subdue the army; afterwards, for ninety days the empire [will] be in great disorder. On the forthcoming ${ }^{54}$ sixth month, heaven [will] emit a sound and earth split open, the Three Dukes and the Nine Chamberlains ${ }^{55}$ [will] all rebel, each [one of them will] establish himself as lord and the victor claim kingship, in violation of the heavenly mandate.

Starting with the physical appearance of the sun at a particular point in time and for a given duration (observational pattern, $\mathrm{X}$ ), the item unfolds a chain of predictions extending to an entire year and ending up with a change in

50 This hypothetical mode has been suggested by an anonymous reviewer.

51 Dongjing 東井, first Lodge of the Southern Palace (Nangong 南宮).

$5^{2}$ All other items in the cluster observe a six-month interval between the month mentioned in the opening statement (here, the sixth month) and the month during which the extrapolated events are said to take place (hence the twelfth, not "tenth," month). Indeed, the tenth month is covered by item $87 / 4$ in the same cluster. Reading sifang 四方 (a common reference to the whole realm) for sifen 四分.

54 Insertion suggested by the syntactical pattern common to all twelve items in the cluster.

55 Two groups of high dignitaries; see Charles O. Hucker, A Dictionary of Official Titles in Imperial China (Stanford: Stanford University Press, 1985), 399 (no. 4871) and 176 (no. 1296). 
sovereignty contrary to heaven's will (extrapolated data, Y). Such a chain of predictions raises a number of questions, including the sources and construction process of such implicative items - the proportional weight of cosmological speculation and historical precedents-and the extent to which the initial observation is subjected to the extrapolated data. ${ }^{56}$

The tentative results of my earlier analysis of all implicative items from our text's remnants may be summarized as follows:

(a) Observational patterns (X) mainly concern astronomical phenomena.

(b) The determinative in observational patterns $(\mathrm{X})$ is always an irregular instance. ${ }^{57}$

(c) Extrapolated data $(\mathrm{Y})$ mainly concern the sphere of human agency (dynastic affairs, governance-including hierarchy and morality-world affairs, and military affairs) while the sphere of non-human agency remains underrepresented.

(d) Extrapolated data (Y) are overwhelmingly negative.

(e) Positive extrapolated data $(\mathrm{Y})$ are very rare and only affect the human sphere.

The present experiment is aimed at confirming, infirming, or qualifying point (a) above. Let us first sample all observational patterns from the surviving items of our text.

The following list of observational patterns unfolds according to the item sequence in the "reconstructed text." (1) Any observation combining at least the following two elements is treated as a "pattern": (a) a named agent, and (b) its-real, apparent or imagined-action or outward appearance. In the first example given above: (a) the earth, (b) its shaking. (2) A few isolated mentions of agents are treated each as a pattern, considering that their mere occurrence virtually constitutes the second element; for instance: in the pattern "hail" (a), the falling (b) is implicit. (3) Items containing more than a single observational pattern may appear more than once..$^{58}$

$5^{6} \quad$ This last question has been suggested by an anonymous reviewer.

57 For a summary discussion of this point, see Grégoire Espesset, "Remarks on Portents Classification and Logic in the Monographs of Han Official Historiography," Bochumer Jahrbuch zur Ostasienforschung / Bochum Yearbook of East Asian Studies 39 (2016): 9-10.

$5^{8}$ The sign " $=$ " marks cases of duplication. Items containing observational patterns amount to 201. Items that do not appear in this sampling are items $73 / 6-7,74 / 1-4,77 / 7$, $85 / 2$, and 9o/2 (auspicious responses to moral qualities); 73/8, 84/1-2, and 95/4 (stellar 
\# Observational pattern (source item or items)

1 Fire coming out of a well 火從井出 $(74 / 7)$

2 Gale uprooting trees 疾風拔木 $(74 / 8)$

3 Red sky with storm uprooting trees and blowing away houses 天赤, 有 大風發屋折木 $(74 / 9)$

4 Raining of grains 天雨粟 $(74 / 10)$

5 Cloud or vapor, ${ }^{59}$ drizzly, not thick 雲氣沐沐不濁 $(75 / 1)$

6 Great fog (or mist) lasting thirty days 大霧 (濛) 三十日 $(75 / 3=92 / 9)$

$7 \quad$ Thunderbolt hitting the Palace 霹靂擊宮 $(75 / 4=75 / 5)$

8 Rainbow appearing 虹出 $(75 / 6=92 / 6)$

9 Five colors in turn illuminating the Palace 五色迭至照於宮 $(75 / 7=$ $75 / 8=92 / 4=92 / 6)$

10 Wry Arrow ${ }^{60}$ of black color 枉矢黑 (75/9)

11 Wry Arrow appearing 枉矢出 (75/10)

Southern or northern location of Wry Arrow 枉矢或南或北 (76/1)

13 Motion of Wry Arrow 枉矢流 (76/2)

14 Boat floating on standing water 澤浮舟 $(76 / 3)$

15 Water flowing upstream 水逆 $(76 / 4,76 / 5=76 / 6,76 / 7=76 / 8=76 / 9)$

16 [Water flowing upstream and] carrying sediment 揚沙 $(76 / 5=76 / 6)$

17 Palace tree emitting noise spontaneously 宮桂自鳴 $(76 / 10=76 / 11=$ $85 / 3)$

18 Earthquake 地震 $(77 / 1=86 / 4,84 / 5)$

19-20 White fox arriving 白狐至 or not arriving 不至 $(77 / 2=97 / 9)$

21 Ox bellowing in the Palace 宮有牛鳴 $(77 / 3=77 / 4=93 / 9)$

22 Crickets gathering 蟋蟀集 $(77 / 5)$

23-25 Large wasp at Court 朝有大蜂, red wasp 蜂赤, or black [wasp] 黑 $(77 / 6)$

26 Palace tiles falling spontaneously 宮瓦自墜 $(77 / 9=77 / 10=93 / 8)$

27 Palace tiles flying off 宮瓦飛 (77/11)

28 Great snowfall 大雪 $(77 / 12)$

explanations); $74 / 5$ (logographic explanation); 74/6, 77/8, and 86/13 (admonitions to the sovereign); 75/2 (meteorological explanation); 84/6 (quintuple typology of phoenix calls); 86/2 (a fragment of uncertain nature); 86/3 (people startled by saintly persons); $91 / 4-5$, 91/8-9, and 97/6 (stellar correlations); 93/1 (fivefold correlations of flavors and viscera); 96/5 (typology of auspicious and inauspicious celestial objects); 97/7-8 (narrative items); and $98 / 8$ (sevenfold typology of wind).

59 For the meaning of clouds (yun 雲) and vapor ( $q i$ 氣) in the context of uranic observation, see He Bingyu 何丙郁 [Ho Peng Yoke] and He Guanbiao 何冠彪, Dunhuang canjuan zhan yunqi shu yanjiu 敦煌殘卷占雲氣書研究 (Taipei: Yiwen yinshuguan, 1985), 5-22. 
29 Snowfall for consecutive months 天雪連月 $(77 / 12)$

30-89 Solar eclipse 日蝕 on sexagesimal cycle days $(78 / 1-82 / 11,82 / 12=$ $83 / 1,=83 / 2)^{61}$

90 Second star of Dipper ${ }^{62}$ changing color, faintly red, dim 斗第二星變 色, 微赤, 不明 $(84 / 3)$

91 Total solar eclipse 日蝕既 (84/4)

92 Quelling Star ${ }^{63}$ scintillating 64 鎮星為動 $(84 / 5)$

93 Woman transforming into man 女子化為丈夫 $(84 / 7=85 / 1)$

94 Man transforming into woman 丈夫化為女子 $(84 / 7=85 / 4)$

95-96 Local Soil God altar emitting noise 里社鳴, roaring 呴 $(85 / 5=85 / 6=$ $86 / 1)$

$97 \quad$ Earth faulting 地裂 $(86 / 5,95 / 12)$

98 Earth emitting noise and fissuring 地鳴而坼 (86/6)

99-100 Earth emitting sound 地鳴有聲 or deep sound 有聲洞洞 $(86 / 7=$ 86/8, 86/9)

101 Earth disgorging blood 地嘔血 $(86 / 10,90 / 3)$

102 Earth emitting light 地生光 $(86 / 11=86 / 12=96 / 7)$

103-114 Variations in solar photosphere 日色 $(87 / 1-89 / 4)$

115 Two suns rising together ${ }^{65}$ 兩日並出 $(90 / 1)$

116 Solar eclipse 日蝕 $(90 / 3-4)$

117 Raining of locusts 天雨蝗 $(90 / 3)$

118 Birds flying all around 鳥旁蜚 $(9 \circ / 3)$

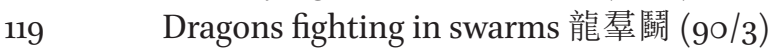

120 Tall person intruding into the Palace 長人入宮 $(9 \circ / 3)$

121 Tiger weeping 虎哭 $(9 \circ / 3)$

122 Pheasant nesting in a tree 66 雉巢 $(9 \circ / 3)$

123 Constellation vanishing 列宿滅 $(90 / 3)$

61 Item 83/2 duplicates the whole preceding series, albeit with omissions and variants.

62 Dou 斗, here the Beidou 北斗 (Northern Dipper) constellation, the seven brightest stars of Ursa Major (UMa). An early name of its second star, $\beta$ UMa (Merak), was Xuan 旋 (Rotator).

63 Zhenxing 鎮星, Saturn.

64 For dong 動 denoting astral scintillation, see Ho Peng Yoke, The Astronomical Chapters of the Chin Shu: With Amendments, Full Translation and Annotations (Paris: Mouton, 1966), 40.

65 A phenomenon called "parhelion" in atmospheric optics; also known as "sundog" or "mock sun." See Ho Ping-Yü [Ho Peng Yoke] and Joseph Needham, "Ancient Chinese Observations of Solar Haloes and Parhelia," Weather 14, no. 4 (1959): 124-134.

66 Common pheasants normally nest on the ground. 
Ten moons rising together ${ }^{67}$ 十月並出 $(90 / 5)$ Moon intruding ${ }^{68}$ upon Winnowing Basket ${ }^{69}$ 月入箕中 $(91 / 1)$ Stars falling ${ }^{70}$ like rain 星隕如雨 $(91 / 2)$ [Celestial] Flail and [Celestial] Lance ${ }^{71}$ 棓槍 seemingly intertwining rays 芒交若 $(91 / 3)$

Chi You's Banner ${ }^{72}$ [appearing] 虫尤之旗 $(91 / 6)$

Resplendent Brilliance ${ }^{73}$ rising 昭明起 (91/7)

Imprisoned $\mathrm{Han}^{74}$ [appearing] 獄漢 (91/10)

Decade's Beginning ${ }^{75}$ [appearing] 旬始 $(91 / 11)$

Wry Arrow occupying ${ }^{76}$ Tumulus ${ }^{77}$ 枉矢守虛 (91/12)

Wry Arrow occupying Quelling Star 枉矢守鎮星 (91/13)

[Wry Arrow occupying Quelling Star], emitting large rays 大芒 (91/13)

Star overgrowing ${ }^{78}$ in Major Indicator ${ }^{79}$ 有星茀於大辰 $(91 / 14)$

67 Perhaps a rare case of "paraselene," also known as "moondog" or "mock moon," a phenomenon comparable to the parhelion mentioned above.

$68 R u$ 入 refers to stellar motion from outside a constellation or celestial body or area into its center. See Ho, The Astronomical Chapters of the Chin Shu, 37.

$69 \mathrm{Ji}$ 箕, seventh Lodge of the Eastern Palace (Donggong 東宮).

70 Xing yun 星隕, meteorites. See Joseph Needham with Wang Ling, Science and Civilisation in China, vol. 3, Mathematics and the Sciences of the Heavens and the Earth (Cambridge: Cambridge University Press, 1959), 433. "Stars falling like rain": meteoric shower.

71 Pei Qiang 棓槍, for Tianpei 天棓, a five-star constellation in Draco and Hercules, and Tianqiang 天槍, a three-star constellation belonging to Boötes, respectively located to the right and left sides of the Purple Palace (Zigong 紫宮), the centermost area of the nightly sky as observed from Earth, believed to be the seat of the celestial monarchy.

72 A comet with a long, curved tail, described in Shiji, 27.1335; see Pankenier, Astrology and Cosmology in Early China, 114, n.58.

73 A large, white star of changing appearance, described in Shiji, 27.1333. See Pankenier, Astrology and Cosmology in Early China, 494, n.249.

74 A northern, large moving star; see Shiji, 27.1334. Pankenier, Astrology and Cosmology in Early China, 495, n.252, hypothesizes a connection with the aurora borealis.

75 A star observed next to the Northern Dipper, described in Shiji, 27.1336. See Pankenier, Astrology and Cosmology in Early China, 496, n.259.

76 Shou 守 refers to stellar station near a constellation or celestial body or area, or inside a constellation or celestial area. See Ho, The Astronomical Chapters of the Chin Shu, 36 .

$77 \mathrm{Xu}$ 虛, fourth Lodge of the Northern Palace (Beigong 北宮).

78 Xing fu 星茀. Fuxing 茀星 (Overgrown Star) refers to a type of comet.

79 Dachen 大辰, one of three seasonal indicators: Big Fire (Dahuo 大火), which is Antares ( $\alpha$ Scorpionis), in the center of Heart (Xin 心), fifth Lodge of the Eastern Palace; or the three-star constellation Attack (Fa 伐) in Triaster (Shen 參), seventh Lodge of the Western Palace (Xigong 西宮), in Orion; or the Northern Polar (Beiji 北極) Star. Alternatively, the fourth, fifth, and sixth eastern Lodges, corresponding to Scorpio: Chamber (Fang 房), 
136

137

138

139

140

141

142

143

Star shooting up ${ }^{80}$ in Northern Dipper 星孛於北斗 $(92 / 1)$

Rays of Sweeping Star ${ }^{81}$ appearing in Pivot of the Dipper ${ }^{82}$ 彗星芒 出於斗樞 $(92 / 2)$

\section{Male and female rainbows ${ }^{83}$ [appearing] 虹蜺 (92/3)}

Five female rainbows appearing together 五蜺俱出 $(92 / 5)$

Mountain emitting light 山有長光 $(92 / 7)$

Earth emitting fiery light 地出光如火照 $(92 / 8)$

Person entering the Palace 有人入宮 $(92 / 10=92 / 11,92 / 12=92 / 13)$

Person walking into the Palace, name unknown 有人走入宮, 不知 其名 $(92 / 12=92 / 13)$

\section{Person born with five heads 人生五首 (93/2)}

Emperor's bell ringing spontaneously 天子鐘自鳴 (93/3)

Weapon flying spontaneously 兵鐵自飛 (93/4)

Drum sounding spontaneously 鼓自鳴 (93/5)

Tiger with two mouths 虎兩口 (93/6)

Rodents eating tree fruits 鼠食木菓 (93/7)

Imperial horse neighing while in motion 天子馬行而鳴 (94/1)

Horse walking into the Palace 有馬走入宮 $(94 / 2=94 / 3)$

Horse neighing and walking [into Palace] 馬有鳴走 $(94 / 2=94 / 3)$

Dragon coming out of a well 龍從井出 (94/4)

Solar or lunar eclipse 日月食之 $(94 / 5,95 / 9)$

Large snake appearing at Court 朝有大蛇見 (94/6)

Birth of locusts 生蝗蟲 $(94 / 6)$

Two-legged animal with red mouth 蟲兩足赤口 $(95 / 1=95 / 2)$

Five-colored star intruding upon side of sun or moon 星有五色流入 日月之傍 $(95 / 3)$

Nine Pits ${ }^{84}$ constellation setting in the South 九坎入南 $(95 / 5)$

Black cloud trespassing ${ }^{85}$ Stride $^{86}$ 黑雲犯奎 $(95 / 6)$

Heart (Xin), and Tail (Wei 尾). See Needham with Wang, Science and Civilisation in China, 3: 249-25o; Pankenier, Astrology and Cosmology in Early China, 59.

8o Xing bei 星孛. Beixing 孛星 (Shooting Star) refers to a comet in opposition, according to Needham with Wang, Science and Civilisation in China, 3: 431.

$81 \quad$ Huixing 彗星, another type of comet.

82 Doushu 斗樞, corresponding to $\alpha$ UMa (Dubhe).

83 Hong 虹 was traditionally viewed as the Yang, male (xiong 雄), primary rainbow, and ni 蜺 as its female ( $c i$ 䧳), Yin counterpart, probably the secondary rainbow.

84 Jiukan 九坎, a nine-star constellation in the Ox (Niu 牛) Lodge of the Northern Palace.

85 Fan 犯, here cloud motion followed by partial occultation. For all uranic phenomena covered by the logogram, see Ho, The Astronomical Chapters of the Chin Shu, $36-37$.

86 Kui 奎, first Lodge of the Western Palace. 
161

162

164

165

166

167

168

169

170

171

172

173

174

175

176

177

178

179

180

181

182

183

184

185

186

187

Black cloud obscuring Southern Lodges ${ }^{87}$ 黑雲蔽於南方之宿 $(95 / 7)$

Solar eclipse with great cold 日食大寒 $(95 / 8)$

Frost falling on sixth month 六月隕霜 (95/10)

Hail 雹 $(95 / 11)$

Landslide in public place 地陷市朝 (96/1)

Landslide in private place 地陷人家 (96/1)

Earth growing hair 地生毛 (96/2)

Bright star trespassing Year Star ${ }^{88}$ and occupying it 歲星居舍陽星流 入犯守 $(96 / 3)$

Meteor trespassing Pasture ${ }^{89}$ 流星犯婁 $(96 / 4)$

Vapor in Stomach and Sunset ${ }^{90}$ 胃昂有氣 $(96 / 6)$

Stomach and Sunset changing color 胃昂變色 (96/6)

2 Mountain stone emitting roar 山石鳴吼 (97/1)

Fire burning down ancestral temple [or] Soil God altar 火焚祠社 (97/1)

Absence of fish in water 水無魚 $(97 / 2)$

Soil piling up into mountain 土雍成山 (97/3)

6 Stone standing erect like human 石立如人 (97/4)

[Stone standing erect like human] in mountain 於山 (97/4)

[Stone standing erect like human] on earth 地 $(97 / 4)$

[Stone standing erect like human] in large stream of water 大水 (97/4)

[Stone standing erect like human] in canal or standing water 溝澤 (97/4)

1 Center of [erect] stone emitting smoke 石中出烟 (97/4)

Ground not cold in winter 冬土不寒 $(97 / 5)$

Long-lasting rainfall 久雨 $(98 / 1)$

4 Water gushing forth in mountain 山 [石浦] (水涌) ${ }^{91}$ 出 $(98 / 2)$

Mountain stone moving 山石行 (98/3)

Sound in center of a well 井中吒 $(98 / 4)$

Well [water] bubbling up 井沸 $(98 / 5)$

87 The Southern Lodges are Eastern Well (Dongjing), Manes (Gui 鬼), Willow (Liu 柳), Seven Stars (Qixing 七星), Strung Bow (Zhang 張), Wings (Yi 翼), and Chariot Baseboard (Zhen 輸).

88 Suixing 歲星, Jupiter.

89 Lou 婁, second Lodge of the Western Palace.

9o Wei 胃 and Mao 昂, third and fourth Lodges of the Western Palace.

91 Tentative correction suggested by a parallel passage from the Weft of the Changes: Comprehensive Hexagram Verification (Yiwei tongguaxian 易緯通卦驗) in Jüshü isho shüsei, vol. 1: Eki 易, part 2 (Tokyo: Meitoku, 1985), 41. 
191 Sandstorm uprooting trees, blowing away houses 風折木發屋飛石 走沙 (98/9)

This list reveals thematic clusters created by the Japanese editors in the process of reconstructing the text. In a preliminary analysis I had divided all observed phenomena into four groups subdivided into eleven subgroups, using a nomenclature only vaguely reflecting the classification principles contemporaneous with the earliest mentions of the Weft book title under consideration. "Uranology" and its subdivision "Astronomy" were by far the dominant groups. ${ }^{92}$

\section{Observational Patterns and Han Classification of Portents}

Now I reorganize this material according to the official Han interpretative framework rather than Western categories inspired by modern scientific disciplines. For classifying book titles, one of the best firsthand models would be the bibliographic categories created by Liu Xin 劉歆 (46 BCE-23 CE) and used by Ban Gu in his “Memoir on the Arts and Letters" (“Yiwen zhi” 蓺文志). ${ }^{93}$ But for classifying observed phenomena, the best model available seems to be the corpus of monographs from the three standard histories of the era. Of special relevance are those compositions dealing with celestial phenomena and the Five Agents - the "Portent Treatises," as Mansvelt Beck styled the pair. Chief differences between the relevant compositions in the three sources may be sketched as follows.

The prototype of all dynastic histories, Records of the Historiographer (Shiji 史記), undertaken by SimaTan 司馬談 (circa180-110 B CE) and completed before 90 BCE by Sima Qian 司馬遷 $\left(145^{-8} 7\right.$ BCE $)$, includes eight monographs, none of which is devoted to the Five Agents. Fifth in the series, the "Documents on the Celestial Offices" (“Tianguan shu” 天官書) reviews descriptive astronomy,

\footnotetext{
92 "Uranology," 119 items ("Astronomy," 101; "Meteorology," 18); "Geology," 27 items ("Seismology," 19; "Hydrology," 6; "Geography," 2); "Sociology," 24 items ("Material Culture," 17; "Anthropology," 7); and "Zoology," 18 items ("Mammalogy," 10; "Entomology," 5; "Ophiology," 2; "Ichthyology," 1). Duplicates are included.

93 See Han shu, 30.1701. Liu's classificatory principles were exposed in his Seven Epitomes (Qilüe 七略), derived from his catalogue, the Separate Lists (Bie lu 別錄). See Hur-Li Lee and Wen-Chin Lan, "Proclaiming Intellectual Authority Through Classification: The Case of the Seven Epitomes," Knowledge Organization 38, no. 1 (2011): 25-42.
} 
political astrology, and a chronology of celestial events. ${ }^{94}$ This monograph served as basic model for the "Memoir on the Celestial Signs" "Tianwen zhi" 天文志) included in the Han Documents, sixth of ten monographs..$^{95}$ The main novelty in the latter is an increased amount of astrological data. In the "Memoir on the Five Agents," which he apparently created, Ban Gu arranged his data into eleven classes determined by the Five Agents-in the order (1) Wood ( $m u$ 木), (2) Fire (huo 火), (3) Soil (tu土), (4) Metal (jin 金), and (5) Water (shui 水)—and Five Matters (wushi 五事)—(6) Demeanor (mao 貌), (7) Speech (yan 言), (8) Sight (shi 視), (9) Hearing (ting 聽), and (10) Thought (si 思)—then (11) "Augustness" (huang 皇), a notion covering the person of the sovereign and his actions. These eleven classes, in turn, are divided into a number of subclasses. ${ }^{96}$ Both homonymous monographs in the Later Han Documents, fourth and fifth of eight "Memoirs," are heavily indebted to those in the Han Documents. ${ }^{97}$ Sima Biao's most conspicuous interventions are the confinement of all comets to his "Memoir on the Celestial Signs"-whereas some were also mentioned in Ban Gu's "Memoir on the Five Agents" - and, as an appendix, of two cases of meteorites (yunshi 隕石)—a subclass included in their own "Memoir on the Celestial Signs" by Ma Xu and his associates. ${ }^{98}$ A simplification of Ban Gu's classification, Sima Biao's own "Memoir on the Five Agents" comprises six synthetic classes only-(1) Wood/Demeanor, (2) Metal/Speech, (3) Fire/Sight, (4) Water/Hearing, (5) Soil/Thought, and (6) Augustness - with subclasses by and large corresponding to those found in its model, though occasionally reorganized and renamed. ${ }^{99}$

94 Translated in Pankenier, Astrology and Cosmology in Early China, 444-511.

95 Parts of the Han Documents were reportedly incomplete when Ban Gu died in 92. The "Memoir on the Celestial Signs" were completed in 111 by Ma Xu 馬續 (before 79after 141) and others under the editorship of Ban Gu's sister Ban Zhao 班昭 (49-116). See A.F.P. Hulsewé, "Notes on the Historiography of the Han Period," in Historians of China and Japan, ed. W.G. Beasley and E.G. Pulleyblank (London: Oxford University Press, 1961), 39 .

96 See Mansvelt Beck, The Treatises of Later Han, 131-141.

97 According to Mansvelt Beck, The Treatises of Later Han, 156-174, both monographs were compiled by Sima Biao in the late third century, using earlier material ascribed to Cai Yong, to Ying Shao 應劭 (fl. 168-197), a specialist of bureaucracy, the law and portents observation, to Dong Ba 董巴 (?-after 220), a historian and a specialist of the calendar, and to Qiao Zhou 譙周 (199-270), a statesman and astronomer. On these figures and their areas of expertise, see Rafe de Crespigny, A Biographical Dictionary of Later Han to the Three Kingdoms (Leiden: Brill, 2007), 148, 704, and 987.

98 That latter arrangement might betray a later intervention, as convincingly suggested by Mansvelt Beck, The Treatises of Later Han, 115 and 144-145.

99 See Mansvelt Beck, The Treatises of Later Han, 142-144; and the comparative analysis of Ban Gu's and Sima Biao's classificatory schemes in Espesset, "Remarks on Portents 
The reference framework below, in which the 191 observational patterns from the remnants of the Qiantan ba are distributed, comprises (1) a list of "Celestial Signs," followed by (2) a list of "Five Agents." Since the homonymous monographs in the Han Documents are more or less contemporaneous with the appearance of the title "Qiantan $b a$," they served in my analysis as models for both lists. The first list, however, includes the "meteorite" subclass, following both the Later Han Documents and Records of the Historiographer. The Later Han Documents serve for occasional reference purpose in the second list. The resulting sequence does not claim to be a faithful reconstruction of Han or Later Han official nomenclature of omens; it is only intended to provide a theoretical groundwork to chart our observational patterns within the limits of the present experiment. ${ }^{100}$

\section{Celestial Signs}

(1.1) Astronomy

- The Offices (guan 官)

- The Five Planets (wuxing 五星)

\#90, 127, 159, 170-171

\#92, 168

(1.2) Astrological theory

- [Auspicious and inauspicious] stars (xing 星) $\quad \#_{10-13}, 123,128-137,158,169$

- Solar (ri 日) and Lunar (yue 月) [phenomena] \#115, 124-125, 154

- Clouds and vapor (yun qi 雲氣)

- Meteorites (yunshi 隕石)

(1.3) Chronology

\#5, 16o-161

\#126

(empty)

\section{Five Agents}

\section{(2.1) Wood}

- Constant rain (changyu 常雨) \#183

(2.2) Fire

- Conflagration and arson (zaihuo 災火) ${ }^{101} \quad$ \#1, 173

- Iron objects flying (tie fei 鐵飛) \#146

(2.3) Soil

(empty)

(2.4) Metal

- Stone emitting sound (shiming 石鳴) $\quad \#_{172}$

Classification and Logic in the Monographs of Han Official Historiography," 18-22 and 34-38, Table 2 .

100 Elements between square brackets are my addition. Numbers in the right column refer to the patterns as numbered in the list above.

101 I borrow the name of this subclass from Hou Han shu, "Zhi," 14.3291. 


\section{(2.5) Water}

- Flooding (dashui 大水) $)^{102}$

$\# 14-16,187^{103}$

(2.6) Demeanor

- Green omens (qingsheng qingxiang 青青青祥) ${ }^{104}$

$\# 149$

- Metal obstructing Wood (jin li mu 金沴木) ${ }^{105}$

\#26-27

(2.7) Speech

- Anomaly of furry animal (maochong nie 毛蟲㩐)

\#121, 148

- White omens (baisheng baixiang 白晧白祥) ${ }^{106}$

\section{(2.8) Sight}

- Persistent warmth (hengyu 恆燠 $)^{107}$

- Vegetable deviance (caoyao 草妖) ${ }^{108}$

- Anomaly of feathered animal (yuchong nie 羽蟲䔣)

- Red omens (chisheng chixiang 赤青赤祥)

(2.9) Hearing

- Persistent cold (henghan 恆寒) 109

- Percussive deviance (guyao 鼓妖) ${ }^{110}$

- Piscine anomaly (yunie 魚酕)

- Anomaly of carapaced animal ( jiechong nie 介蟲䔣)

$$
\text { \#19-20, 167, 176-181 }
$$

$\# 182$

\#4

\#118, 122

\#101, 157, 188-190

\#28-29, 163-164

\# $7,17,95-96,99-100$,

$145,147,186$

\#174

\#22-25, 117, 156

\section{(2.10) Thought}

- Persistent wind (hengfeng 恆風)

- Bovine disaster (niuhuo 牛禍)

\#2-3, 191

$\# 21$

- Yellow omens (huangsheng huangxiang 黃青黃祥)

\#102, 140-141, $175^{111}$

102 In Hou Han shu, "Zhi," 15.3311, the corresponding subclass includes water "flowing upstream" (ni liu 逆流), at which point Li Xian's commentary cites item 76/4 from our text.

103 Shen Yue's 沈約 (441-513) "Memoir on the Five Agents" ("Wuxing zhi”; completed between 488 and 502) in his Song Documents (Song shu 宋書) has a similar subclass that includes “well water bubbling up and overflowing” (jingshuifuyi 井水沸溢); see Song shu (Beijing: Zhonghua shuju, 1974), 33.953.

104 In Han shu, 27BA.1372-1374, this subclass lists cases involving rodents (shu 鼠).

105 The corresponding subclass in Hou Han shu, "Zhi," 13.3265, is called "building deteriorating spontaneously" (wuzihuai 屋自壞).

106 Several cases of "earth growing hair" are listed in the same subclass in Shen Yue's homologous monograph in Song shu, 31.924-925.

107 In Han shu, 27BB.1407-1409, this subclass has “iceless" (wubing 無冰) winter and spring.

108 In Han shu, 27BB.1414, this subclass has a "raining of plants" (tian yu cao 天雨草).

109 In Han shu, 27 BB.1422-1428, this subclass includes "raining of snow" ( yu xue 雨雪), "falling of frost" (yun shuang 隕霜), and “hail” (bao 雨).

110 In Han shu, 27BB.1428-1430, various sonic phenomena are included in this subclass.

111 Due to their involving earth, I tentatively ascribe all four phenomena to this subclass. 
- Earthquake (dizhen 地震)

- Mountain collapsing (shan beng 山崩) ${ }^{112}$

$\# 18$

\#97-98, 165-166,

$184-185$

\section{(2.11) Augustness}

- Persistent overcast (hengyin 恆陰)

\#6

- Draconic and ophidian anomaly (longshe nie 龍蛇䓔) \#119, 153, 155

- Equine disaster (mahuo 馬禍)

- Human malady (renke 人痾) ${ }^{113}$

$\# 150-152$

- Cast female rainbow (touni 投蜺) ${ }^{114}$

- Solar eclipse (rishi 日蝕)

- Abnormal sun (yiri 異日)

$\# 8-9,138-139$

\#30-89, 91, 116, 162

\#103-114

The table on the next page summarizes the amount of observational patterns distributed in each class in the preceding list. ${ }^{115}$

Thus reorganized according to "Han" portents nomenclature, our materials offer quite a nuanced picture. Whereas most patterns fell under "astronomy" or "meteorology" when using a classification inspired by the Western categories, our sample now overwhelmingly concerns the "Five Agents" phenomenology $(83.2 \%)$, more particularly signs betraying a dysfunction of sovereignty within the eleventh class, Augustness (48.2\%). This change is easily accountable for. Classified as celestial phenomena in the early Han era (as per Records of the Historiographer), solar eclipses entered Five Agents portentology with Ban Gu's founding monograph, followed in this regard by Sima Biao. Solar eclipses, with a total of 63 patterns (about one third of the sample), prove decisive in defining

112 In Han shu, 27CA.1451-1457, cases of "earthquake" and of "mountain collapsing" form the subclass "Metal, Wood, Water, and Fire obstructing Soil" (jin mu shui huo li tu 金木水 火沴土). Here I follow the Hou Han shu, "Zhi," 16.3332-3334, where the corresponding three subclasses, "landslide” (dixian 地陷), "earthquake," and "mountain collapsing," also include cases of "earth faulting" (di lie 地裂) and "earth fissuring" (diche 地坼).

113 In Han shu, 27CA.1471-1477, this subclass is called "malady of inferior people attacking superior” (xiaren fa shang zhi ke 下人伐上之疴) but lists cases of human oversize, gender change, apparent death followed by resurrection, abnormal human birth, human deformity, and odd human behavior. The heading of my subclass is borrowed from the seemingly more appropriate Hou Han shu, "Zhi," 17.3341.

114 I tentatively ascribe rainbow-related items to this subclass borrowed from Hou Han shu, "Zhi," $17 \cdot 3341$ and $17.335^{-}-335^{2}$, which cites items $75 / 6$ and 92/6 from our text.

115 The column "=" gives absolute values. The column "\%" gives relative values rounded to the nearest tenth. 


\begin{tabular}{|c|c|c|c|c|c|}
\hline \multicolumn{2}{|c|}{ Portents Nomenclature } & \multicolumn{2}{|c|}{ Amount } & \multicolumn{2}{|c|}{ Total } \\
\hline Monographs & Classes & $=$ & $\%$ & $=$ & $\%$ \\
\hline \multirow[t]{3}{*}{ 1. Celestial Signs } & (1.1) Astronomy & 7 & $3 \cdot 7 \%$ & 32 & $16.8 \%$ \\
\hline & (1.2) Astrological theory & 25 & $13.1 \%$ & & \\
\hline & (1.3) Chronology & - & - & & \\
\hline \multirow[t]{11}{*}{ 2. Five Agents } & (2.1) Wood & 1 & $0.5 \%$ & 159 & $83.2 \%$ \\
\hline & (2.2) Fire & 3 & $1.6 \%$ & & \\
\hline & (2.3) Soil & - & - & & \\
\hline & (2.4) Metal & 1 & $0.5 \%$ & & \\
\hline & $(2.5)$ Water & 4 & $2.1 \%$ & & \\
\hline & (2.6) Demeanor & 3 & $1.6 \%$ & & \\
\hline & (2.7) Speech & 11 & $5.8 \%$ & & \\
\hline & (2.8) Sight & 9 & $4.7 \%$ & & \\
\hline & (2.9) Hearing & 20 & $10.5 \%$ & & \\
\hline & (2.10) Thought & 15 & $7 \cdot 9 \%$ & & \\
\hline & (2.11) Augustness & 92 & $48.2 \%$ & & \\
\hline Grand Total: & & 191 & $100 \%$ & 191 & $100 \%$ \\
\hline
\end{tabular}

arithmetical precedence among classes, thereby confirming earlier research results on comparable data. ${ }^{116}$ The emphasis laid on solar eclipses as expressing defective authority echoes the speculations about the origin and nature of sovereignty that took place during the Han era, as documented by Weft remnants, among other sources. ${ }^{117}$ Meanwhile, Celestial Signs per se, an ancient science mixing disturbingly — to the modern mind — astronomy, astrology, and meteorology, ${ }^{118}$ become the minority group (16.8\%), and the class "Astrological theory" therein comes second in the whole nomenclature (13.1\%), far behind "Augustness." The figures for all other classes are arguably too low to invite

116 Mansvelt Beck, The Treatises of Later Han, 148, remarked that, with 72 cases (17.2\%), solar eclipses are the most numerous among the 418 portents entered by Sima Biao in his "Memoir on the Five Agents." Earthquakes (6o cases, about 14.4\%) come second.

117 For Weft sources, see Espesset, "Epiphanies of Sovereignty and the Rite of Jade Disc Immersion in Weft Narratives." For other pre- and early imperial sources, see Michael Loewe, The Men Who Governed Han China: Companion to "A Biographical Dictionary of the Qin, Former Han and Xin Periods" (Leiden: Brill, 2004), 421-456 and 549-558.

118 I use the concept of "ancient science" along the lines of Lloyd and Sivin, The Way and the Word, 4-6. 
confident interpretations, but it is interesting to note that patterns coming under the Five Agents classes proper (2.1-2.5) totalize less than $5 \%$ (about $4.7 \%)$, far behind those $(30.4 \%)$ coming under the Five Matters classes $(2.6-2.10)$.

\section{Concluding Remarks}

From a linguistic point of view, most of our Weft patterns match the phraseological properties, if not strictly of "Han" portentology, at least of this lore and its early medieval continuation, which can be approached via the monographs on Celestial Signs and the Five Agents in the historiography of the era. ${ }^{119}$ There cannot be any doubt that whoever compiled the Qiantan ba was knowledgeable about such ancient sciences as stellar nomenclature and interpretation, Yin/Yang theories, and Five Agents correspondences. ${ }^{120}$ In the surviving fragments of the work, however, there is no evidence that the author was familiar with Ban Gu's typology and its sources. Nor is it possible, in view of its current condition, to assume that the original Weft book contained explanations as detailed as those provided by Ban Gu in his monograph. ${ }^{121}$ Nevertheless, some fragments offer explanations of logograms allowing one to glimpse at the unknown author's mind:

\section{(95/9) 蝕之為言責也. 凡日月蝕, 人君當責躬, 以自驚也.}

"Eclipse" means "a blame." [On] every solar [or] lunar eclipse, the lord of men ought to blame his own self, in order to alarm himself.

119 In the early medieval period, only the Wei Documents (Wei shu 魏書), completed in 554 by Wei Shou 魏收 (506-572), whose historiographical method has been criticized, names both monographs "Memoir on the Celestial Images" ("Tianxiang zhi” 天象志) and "Memoir on Numinous Evidences" ("Lingzheng zhi” 靈徵志) respectively. However, their contents show that Wei's variant titles imply no major paradigmatic departure from their models.

120 The celestial bodies named in the fragments match those found in such reconstituted Han star catalogues as Sun and Kistemaker, The Chinese Sky during the Han. As regards the Five Agents, item 93/1 unfolds the usual fivefold correspondences between the Five Viscera (wuzang 五藏) and the Five Flavors (wuwei 五味). Yin and Yang are frequently encountered throughout the reconstituted text, including in the commentaries attached to some items.

121 See the passages discussed and translated in Espesset, "Remarks on Portents Classification and Logic in the Monographs of Han Official Historiography," 10-18. 
This item is fully consonant with Ban Gu's ascription of eclipses to dysfunctions in sovereignty. To my knowledge, the logograms shi ("eclipse") and ze ("blame") are not semantically nor graphically related. But in view of their relative phonetic proximity, the latter may well have served as paronomastic gloss for the former, even though they did not belong to the same rhyme group. ${ }^{122}$

In a further example, the determinative is evidently the unseasonable nature - hence irregularity — of frost in the sixth month, but the proposed justification clearly resorts to paronomasia, as shuang ("frost") and wang ("a loss") belonged to the same rhyme group in Han times:123

(95/10) 霜之為言亡也. 六月隕霜: 君其亡之.

"Frost" means "a loss." (X) Frost falling on the sixth month: $(\mathrm{Y})$ The lord shall be lost.

The Comprehensive Discussions in the White Tiger Pavilion-possibly the source of our anonymous author for this fragment-includes exactly the same definition but then adds "Yang, being dispersed, is lost" (yang yi san wang 陽以散亡) ${ }^{124}$ and does not include the second, extrapolative half of item 95/10. Next example:

(95/11) 䨌之為言薄也. 陰氣專精, 積合為雹.

"Hail" means "thin." The concentrated essences of Yin pneumata gather together to form hail.

Here again, the Comprehensive Discussions present a nearly identical passage, in which bo 薄 (“thin") reads he 合 ("together"). ${ }^{125}$ In view of the explanatory logic at work in all three examples, the latter logogram could be the original reading. But $b o$, also pronounced $b a o$, may well have worked as paronomastic

122 Compare Axel Schuessler, Minimal Old Chinese and Later Han Chinese: A Companion to Grammata Serica Recensa (Honolulu: University of Hawai'i Press, 2009), 110 (蝕 in rhyme group *-ək $z h i$ 職) and 132 (責 in rhyme group *-ek $x i$ 錫).

123 Schuessler, Minimal Old Chinese and Later Han Chinese, 87 and 89 (霜 and 亡, both in rhyme group *-ay yang 陽).

124 Baihu tong shuzheng, 6.271. Cf. Tjan Tjoe Som, Po Hu T'ung: The Comprehensive Discussions in the White Tiger Hall, vol. 2, Translation of Chapters III-XVII, XIX-XXXIX, XLI-XLIII; Fragments (Leiden: E.J. Brill, 1952), 490 ('Shuang 'frost' means wang 'lost'. The yang has dispersed and is lost").

125 Baihu tong shuzheng, 6.271. Cf. Tjan, Po Hu T'ung, 2:49o ("Pao 'hail' means ho 'to coagulate'. The very essence of the yin-fluid accumulates and coagulates to become hail"). 
gloss for bao 雹, at least at later times. ${ }^{126}$ Other sources use it to describe Yin's action upon Yang as causing hail, for instance, the "Memoir on the Five Agents" (“Wuxing zhi”) in the Southern Qi Documents (Nan Qi shu 南齊書), completed in 537 by Xiao Zixian 蕭子顯 (489-537). ${ }^{127}$

More importantly, in the last example below, which comes from a citation in the Comprehensive Discussions, the diachronic logic beneath the implicative genre-in other words, the causal relationship between $\mathrm{X}$ and $\mathrm{Y}$ - is given an explicit formulation:

(74/5) 災之為言傷也, 随事而誅. 異之言怪, 先 (發) $)^{128}$ 感動之也.

"Calamity" means "to injure," to punish according to facts. "Abnormality" means "strange," it is a sent foreboding. ${ }^{129}$

To the mind of our anonymous author, it must have been evident that abnormal occurrences "precede" (xian 先) calamities as warnings, while calamities "follow" (as sui 随 literally means) human actions as their direct consequence. The logograms xian and sui encapsulate anteriority and subsequence. Both sentences could be understood separately, but read jointly (as the Comprehensive Discussions cite them) they seem to imply that human deeds indirectly cause the appearance of abnormal phenomena by provoking future calamities. In this causal system, the triggering instance is human, but calamities and the anomalies portending them are exogenous responses from non-human agencies. Interestingly, in his "Five Agents" monograph, Ban Gu warned his audience of the limited accuracy of the extrapolative process: some signs might appear only in the wake of the events they supposedly forebode, while some might simply never appear. ${ }^{130}$ In sharp contrast with this statement, our Weft book would seem not to accept the possibility of a sequence reversal, that is, that a

126 For Yuan and later times, see Edwin G. Pulleyblank, Lexicon of Reconstructed Pronunciation in Early Middle Chinese, Late Middle Chinese, and Early Mandarin (Vancouver: Universtiy of British Columbia Press, 1991), 30. Compare Schuessler, Minimal Old Chinese and Later Han Chinese, 61 (薄 in rhyme group *-a yu 魚) and 183 (雹 in rhyme group *-u you 幽).

127 See Nan Qi shu (Beijing: Zhonghua shuju, 1972), 19.372, quoting an unspecified exegetic "tradition" (zhuan 傳). For alternative explanations of hail, see Baihu tong shuzheng, 6.271.

128 Insertion suggested by the source of the citation, Baihu tong shuzheng, 6.268.

129 Cf. Tjan, Po Hu T'ung, 2:489 ('Tsai 'calamity' means shang 'to hurt'. According to the [nature of the mis] deed punishment is inflicted. I 'miracle' means kuai 'strange'. [Strange phenomena] appear as presages, to touch and move [the evil-doer]").

130 Espesset, "Remarks on Portents Classification and Logic in the Monographs of Han Official Historiography," 14-15. 
calamity might occur before the sign announcing it is ever observed-indeed quite a rational attitude to the modern mind.

Does this imply that we should understand the extrapolated data in all implicative items as announcing the future and systematically translate them in the grammatical future tense? Perhaps, if we understand "calamity" (zai 災) in the above citation strictly as being a technical reference to the extrapolated element $(\mathrm{Y})$ in all implicative items. Otherwise, on a case-by-case basis, the "calamity" sometimes seems to be more the ultimate outcome of the facts described in element $Y$ than these facts themselves. To take up again the first item cited earlier (77/1), the "calamity" might be less the conspiracy itself $(\mathrm{Y})$ extrapolated from the earthquake $(\mathrm{X})$ than the conspiracy's unspecified longerterm consequences.

To conclude, let us return to the descriptive list (xumu 叙目) of Weft books in Zhao Zaihan's Seven Categories of Weft Writings. Zhao attached the following verse to the title of the Qiantan ba in this list:

\section{陰陽災異, 深潛莫知. 天心弭亂, 委曲維持.}

The calamities and abnormalities ${ }^{131}$ of Yin and Yang are unfathomable and known to none. The suspension of disturbance in the heart of heaven is tortuous to maintain. ${ }^{132}$

Thus was, in the early years of the nineteenth century, summed up the purpose of an ancient, lost Weft book that would primarily address manifestations of cosmic unbalance and offer ways to restore and maintain universal equilibrium (as exemplified by prescriptive and admonitory items, despite their limited amount in the fragmentary reconstructed text). The observational patterns dealt with in that book mostly reflect what the ancient Chinese would regard as departures from that ideal state. As Hans Bielenstein (1920-2015) noted: "Evidently everything could be regarded as a portent which from the Chinese point of view represented a change from the normal condition of things, especially a change for the worse."133

Among the most powerful images that, in the Chinese mind, represented the vitiation of that state, are diametrical inversions of representations

131 English dictionaries usually treat zaiyi 災異 as a compound and render it as "portents." It is clear, however, that our text defines and uses both logograms separately, in particular when contrasting the damaging effects of zai 災 to the deviation encapsulated by $y i$ 異.

132 Qiwei, 38.755.

133 Hans Bielenstein, "An Interpretation of the Portents in the Tsi'en-Han-shu," Bulletin of the Museum of Far Eastern Antiquities 22 (1950): 127. 
reflecting the intrinsic order of things: inversion of morality, as mean people get promoted to replace worthies in the civil service (items 74/10, 75/1, 79/9, $80 / 11,83 / 2,84 / 7,86 / 12,88 / 2,93 / 7,96 / 7,97 / 1)$ and as moral values are denatured while lack of virtue is exalted (items 74/10, 88/2); inversion of hierarchy, when lord and vassal switch positions (items $80 / 1,83 / 2,89 / 3$ ) and minor territorial entities become respected states, and vice versa (item 91/12); and inversion of geographical verticality as valleys turn into elevations, and vice versa (item 88/2). For Zhao Zaihan, all these instances must have seemed to be symbolically equivalent to the inversion in cosmology encapsulated by Yin repressing Yang (items $78 / 9,83 / 2,93 / 4$ ), a takeover also made manifest by women turning into men (items $81 / 13,83 / 2$ ), female dominion over males (items $75 / 6,92 / 6$, 98/5), and inferiors overpowering their lords (item $87 / 4,89 / 2,98 / 1$ ).

TABLE 1 Secondary sources (collections of Weft citations) used in Jūshū isho shūsei to compile Qiantan ba

Identified secondary sources

References in

Jūshū isho shūsei

Source title

Date

Simplified title Items ${ }^{\mathrm{a}}$

$\begin{array}{lllr}\text { Re-collated Shuofu 重校說郛 } & 1646 \text { edition } & \text { 郛 } & 2 \\ \text { Guweishu 古微書 } & \text { Ming (1888 ed.) } & \text { 微 } & 48 \\ \text { Weishu 緯書 } & \text { Ming edition } & \text { 緯 } & 71 \\ \text { Jiwei 集緯 } & \text { Qing edition } & \text { 集 } & 38 \\ \text { Qiwei 七緯 } & 1809 \text { edition } & \text { 七 } & 93 \\ \text { Yuhanshan fang ji yishu 玉函山房輯佚書 } & 1874 \text { edition } & \text { 玉 } & 105 \\ \text { Weijun 緯糜 } & 1877 \text { edition } & \text { 糜 } & 44 \\ \text { Hanxuetang congshu 漢學堂叢書 } & 1893 \text { edition } & \text { 漢 } & 216 \\ \text { Huang shiyishu kao 黄氏逸書考 } & 1937 \text { edition } & \text { 逸 } & 213\end{array}$

a One item only derives from all nine secondary sources $(76 / 7)$ while five items derive from a single secondary source $(84 / 3,91 / 4,92 / 2$, and $98 / 8-9)$. In addition, 26 items for which no secondary source is given - bearing instead the mention "[secondary source] lost in China" (Zhong $y i$ 中佚) — are marked as deriving from a single primary source each (74/1, 75/8, $76 / 2,76 / 6,76 / 9,77 / 4,83 / 1,85 / 2-3,86 / 2-3,92 / 8,93 / 4,94 / 3,95 / 2$, and $97 / 6-98 / 7)$. Of the remaining items, 200 derive from two secondary sources or more-which explains why the sum of the figures in this column (830) is superior to the total number of Qiantan ba itemsand a single one, also marked as having no secondary source in China, derives from two primary sources (85/1). The mention “[ secondary source] lost in Japan" (Ri $y i$ 日佚) appears once, applied to a commentary (within item 74/10) that is marked as deriving from a single primary source. 
TABLE 2 Primary sources used in Jüshū isho shūsei to collate Qiantan ba citations extracted from secondary sources

Identified primary sources
References in

Jūshū isho shūsei

Referred title Items ${ }^{\mathrm{a}}$
Source title

Baihu tong (yi) 白虎通 (義)

Hou Han shu, "Wuxing zhi"

Hou Han shu, "Wuxing zhi," commentary

Caizhonglang ji 蔡中郎集

Wenxuan 文選

Yuzhu baodian 玉燭寶典

Wuxing dayi 五行大義

Beitang shuchao 北堂書鈔

Yiwen leiju 藝文類聚

Guanxiang wanzhan 觀象玩占

Tiandi ruixiang zhi 天地瑞祥志

Hou Han shu, commentary

Chuxue ji 初學記

Da Tang Kaiyuan zhanjing 大唐開元占經

Hifuryaku 秘府略

Jirui 稽瑞

Taiping yulan 太平御覽

Shileifu zhu 事類賦注

Wuxing leishi zhan 五行類事占

Wenxian tongkao 文獻通考

Tang leihan 唐類函

Yuanjian leihan 淵鑑類函

Weishu, Qinghe jun edition 清河郡本緯書
Date

after $79 / 213^{-245}$ ? 白虎通

1

late 3 rd cent.

後漢五行志

early 6th cent.

Liang?

$5^{26-531}$

564-581

circa 594

Sui

624

7 th cent.

666

676

circa 700

718-726

Japan, 831

Tang?

977-982

993

Song?

1317

1603

1710 edition

Qing?
後漢五行志注 3

蔡中郎集 1

選

3

玉燭

2

五行

書鈔 2

㙯

6

觀象玩占 1

天地 20

後漢 ... 注 1

初

5

占

144

秘府略

3

稽瑞

5

覽

事類賦

五行類事占

通考

24

唐

4

淵

清

a Figures in this column express how many times each primary source was used to collate Qiantan ba citations extracted from secondary sources, not the actual number of Qiantan ba citations that each primary source contains. 


\section{Bibliography}

Anju Xiangshan [Yasui Kōzan] 安居香山 and Zhongcun Zhangba [Nakamura Shōhachi] 中村璋八, eds. Weishu jicheng 緯書集成. Shijiazhuang: Hebei renmin chubanshe, 1994.

Baihu tong shuzheng 白虎通疏證. Edited by Chen Li 陳立 and Wu Zeyu 吳則虞. Beijing: Zhonghua shuju, 1994.

Bielenstein, Hans. "An Interpretation of the Portents in the Tsi'en-Han-shu." Bulletin of the Museum of Far Eastern Antiquities 22 (1950): 127-143.

Boltz, William G. "Shuo wen chieh tzu." In Early Chinese Texts: A Bibliographical Guide, edited by Michael Loewe, 429-442. Berkeley: Society for the Study of Early China, and Institute of East Asian Studies, University of California, Berkeley, 1993.

Cao Shujie 曹書杰. “Huang Shi shengzu kao" 黄䙲生卒考. Dongbei shida xuebao (zhexue shehui kexue ban) 東北師大學報（哲學社會科學版）, 1989 no. 6, 109-110.

Chan, Alan K.L. "From Uncrowned King to the Sage of Profound Greatness: Confucius and the Analects in Early Medieval China." In A Concise Companion to Confucius, edited by Paul R. Goldin, 249-267. Hoboken: John Wiley and Sons, 2017.

Cheng, Anne. "Ch'un ch'iu, Kung yang, Ku liang and Tso chuan." In Early Chinese Texts: A Bibliographical Guide, edited by Michael Loewe, 67-76. Berkeley: Society for the Study of Early China, and Institute of East Asian Studies, University of California, Berkeley, 1993 .

De Crespigny, Rafe. A Biographical Dictionary of Later Han to the Three Kingdoms. Leiden: Brill, 2007 .

Di Giacinto, Licia. The Chenwei Riddle: Time, Stars, and Heroes in the Apocrypha. Gossenberg: Ostasien Verlag, 2013.

Dull, Jack L. "A Historical Introduction to the Apocryphal (Ch'an-wei) Texts of the Han Dynasty." PhD diss., University of Washington, Seattle, 1966.

Espesset, Grégoire. "Epiphanies of Sovereignty and the Rite of Jade Disc Immersion in Weft Narratives." Early China 37 (2014): 393-443.

Espesset, Grégoire. Review of The Chenwei Riddle: Time, Stars, and Heroes in the Apocrypha, by Licia Di Giacinto. T'oung Pao 100 (2014): 505-511.

Espesset, Grégoire. "Remarks on Portents Classification and Logic in the Monographs of Han Official Historiography." Bochumer Jahrbuch zur Ostasienforschung / Bochum Yearbook of East Asian Studies 39 (2016): 5-38.

Ess, Hans van. "The Apocryphal Texts (ch'en-wei) of the Han Dynasty and the Old Text/ New Text Controversy." T'oung Pao 85 (1999): 29-64.

Fèvre, Francine. "Drôles de bestioles: Qu'est-ce qu'un Chong?” Anthropozoologica 18 (1993): $57-65$.

Gu Jiegang 顧頴剛. Han dai xueshu shilüe 漢代學術史略. Shanghai: Zhongguo wenhua fuwushe, 1936. 
Gujin tushu jicheng 古今圖書集成. Edited by Chen Menglei 陳夢雷; revised by Jiang Tingxi 蔣廷錫. Beijing: Zhonghua shuju, 1985.

Haeger, John Winthrop. "The Significance of Confusion: The Origins of the T'ai-p'ing yü-lan." Journal of the American Oriental Society 88, no. 3 (1968): 401-410.

Han shu 漢書. By Ban Gu 班固 et al. Beijing: Zhonghua shuju, 1962.

He Bingyu 何丙郁 [Ho Peng Yoke] and He Guanbiao 何冠彪. Dunhuang canjuan zhan yunqi shu yanjiu 敦煌殘卷占雲氣書研究. Taipei: Yiwen yinshuguan, 1985.

Henderson, John B. "Chinese Cosmographical Thought: The High Intellectual Tradition." In Cartography in the Traditional East and Southeast Asian Societies, edited by J.B. Harley and David Woodward, 203-227. Vol. 2, bk. 2, of The History of Cartography. Chicago: University of Chicago Press, 1994.

Ho Peng Yoke. The Astronomical Chapters of the Chin Shu: With Amendments, Full Translation and Annotations. Paris: Mouton, 1966.

Ho Ping-Yü [Ho Peng Yoke] and Joseph Needham. "Ancient Chinese Observations of Solar Haloes and Parhelia." Weather 14, no. 4 (1959): 124-134.

Hou Han ji 後漢紀. By Yuan Hong 袁宏. Beijing: Zhonghua shuju, 2002.

Hou Han shu 後漢書. By Fan Ye 范瞱 et al. Beijing: Zhonghua shuju, 1965.

Hucker, Charles O. A Dictionary of Official Titles in Imperial China. Stanford: Stanford University Press, 1985 .

Hulsewé, A.F.P. "Notes on the Historiography of the Han Period." In Historians of China and Japan, edited by W.G. Beasley and E.G. Pulleyblank, 31-43. London: Oxford University Press, 1961.

Kalinowski, Marc. General introduction (introduction générale) to Divination et société dans la Chine médiévale: Étude des manuscrits de Dunhuang de la Bibliothèque nationale de France et de la British Library, edited by Marc Kalinowski, 6-33. Paris: Bibliothèque nationale de France, 2003.

Kaltenmark, Max. "Les Tch'an-wei." Han-Hiue: Bulletin du Centre d'études sinologiques de Pékin 2, no. 4 (1949): 363-373.

Lee, Hur-Li, and Wen-Chin Lan. "Proclaiming Intellectual Authority Through Classification: The Case of the Seven Epitomes." Knowledge Organization 38, no. 1 (2011): 25-42.

Li Meixun 李梅訓. “Song Jun shengping zhushu kaolun” 宋均生平著述考論. Shandong shifan daxue xuebao (renwen shehui kexue ban) 山東師範大學學報（人文社會科 學版) 49, no. 5 (2004): 90-93.

Liddell, Henry G., and Robert Scott. Greek-English Lexicon. 7th ed. New York: Harper and Brothers, 1883 .

Lloyd, Geoffrey, and Nathan Sivin. The Way and the Word: Science and Medicine in Early China and Greece. New Haven: Yale University Press, 2002.

Loewe, Michael. "Pai hu t'ung." In Early Chinese Texts: A Bibliographical Guide, edited by Michael Loewe, 347-356. Berkeley: Society for the Study of Early China, and Institute of East Asian Studies, University of California, Berkeley, 1993. 
Loewe, Michael. The Men Who Governed Han China: Companion to "A Biographical Dictionary of the Qin, Former Han and Xin Periods.” Leiden: Brill, 2004.

Loewe, Michael. Dong Zhongshu, a "Confucian" Heritage and the "Chunqiu Fanlu." Leiden: Brill, 2011.

Lü Kai 呂凱. ZhengXuan de chenweixue 鄭玄的驖緯學. 2nd ed. Taipei: Taiwan shangwu yinshuguan, 2011.

Lu, Zongli. Power of the Words: Chen Prophecy in Chinese Politics, AD 265-618. Bern: Peter Lang, 2003.

Lynn, Richard J. The Classic of Changes: A New Translation of the I Ching as Interpreted by Wang Bi. New York: Columbia University Press, 1994.

Mansvelt Beck, B.J. The Treatises of Later Han: Their Author, Sources, Contents and Place in Chinese Historiography. Leiden: Brill, 1990.

Nan Qi shu 南齊書. By Xiao Zixian 蕭子顯. Beijing: Zhonghua shuju, 1972.

Needham, Joseph, with Wang Ling. Mathematics and the Sciences of the Heavens and the Earth. Vol 3 of Science and Civilisation in China. Cambridge: Cambridge University Press, 1959 .

Nielsen, Bent. A Companion to Yi Jing Numerology and Cosmology: Chinese Studies of Images and Numbers from Han 漢 (202 BCE-220 CE) to Song 宋 (960-1279 CE). London: RoutledgeCurzon, 2003.

Nylan, Michael. The Five "Confucian" Classics. New Haven: Yale University Press, 2001.

Nylan, Michael. "Kongzi, the Uncrowned King." In Lives of Confucius: Civilization's Greatest Sage through the Ages, by Michael Nylan and Thomas Wilson, 67-100. New York: Doubleday, 2010.

Nylan, Michael. “Yin-Yang, Five Phases, and Qi.” In China's Early Empires: A Re-Appraisal, edited by Michael Nylan and Michael Loewe, 398-414. Cambridge: Cambridge University Press, 2010.

Pankenier, David W. Astrology and Cosmology in Early China: Conforming Earth to Heaven. Cambridge: Cambridge University Press, 2013.

Pulleyblank, Edwin G. Lexicon of Reconstructed Pronunciation in Early Middle Chinese, Late Middle Chinese, and Early Mandarin. Vancouver: University of British Columbia Press, 1991.

Qi Zhaonan 齊召南. Chunqiu Gongyang zhuan zhushu kaozheng bayu 春秋公羊傳注疏 考證跋語. In Siku quanshu.

Quan Hou Han wen 全後漢文. By Yan Kejun 嚴可均. Beijing: Zhonghua shuju, 1995 .

Rochberg, Francesca. “If P, then Q': Form and Reasoning in Babylonian Divination.” In Divination and Interpretation of Signs in the Ancient World, edited by Amar Annus, 19-27. Chicago: The Oriental Institute of the University of Chicago, 2010.

Schuessler, Axel. Minimal Old Chinese and Later Han Chinese: A Companion to Grammata Serica Recensa. Honolulu: University of Hawai'i Press, 2009.

Shuowen jiezi 說文解字. By Xu Shen 許慎. Beijing: Zhonghua shuju, 1963. 
Sivin, Nathan. "State, Cosmos, and the Body in the Last Three Centuries B.C." Harvard Journal of Asiatic Studies 55 (1995): 5-37.

Song shi 宋史. By Tuotuo 脱脱 (Toghto) et al. Beijing: Zhonghua shuju, 1985.

Song shu 宋書. By Shen Yue 沈約 et al. Beijing: Zhonghua shuju, 1974.

Strassberg, Richard E. A Chinese Bestiary: Strange Creatures from the Guideways Through Mountains and Seas. Berkeley: University of California Press, 2002.

Sun Jue 孫瑴. Guweishu 古微書. In Siku quanshu.

Sun, Xiaochun, and Jacob Kistemaker. The Chinese Sky during the Han: Constellating Stars and Society. Leiden: Brill, 1997.

Taiping yulan 太平御覽. Edited by Li Fang 李昉. Shijiazhuang: Hebei jiaoyu chubanshe, 1994.

Tjan Tjoe Som. Po Hu T'ung: The Comprehensive Discussions in the White Tiger Hall. Vol. 1, Introduction; Translation of Chapters I, II, XVIII, XL; Notes: A Contribution to the History of Classical Studies in the Han Period. Leiden: E.J. Brill, 1949.

Tjan Tjoe Som. Po Hu T'ung: The Comprehensive Discussions in the White Tiger Hall. Vol. 2, Translation of Chapters III-XVII, XIX-XXXIX, XLI-XLIII; Fragments. Leiden: E.J. Brill, 1952.

Tseng, Lillian L. Picturing Heaven in Early China. Cambridge, MA: Harvard University Asia Center, 2011.

Wang, Aihe. Cosmology and Political Culture in Early China. Cambridge: Cambridge University Press, 2000.

Wei shu 魏書. By Wei Shou 魏收. Beijing: Zhonghua shuju, 1974.

Yasui Kōzan 安居香山. “Dai Tō Kaigen senkyō ihonkō” 大唐開元占經異本考. Tōkyō kyōiku daigaku bungakubu kiyō 東京教育大學文學部紀要 32 (1961): 1-83.

Yasui Kōzan 安居香山 and Nakamura Shōhachi 中村璋八. Isho no kisoteki kenkyū 緯書 の基礎的研究. Tokyo: Kan-Gi bunka kenkyūkai, 1966.

Yasui Kōzan 安居香山 and Nakamura Shōhachi 中村璋八, eds. Isho shūsei 緯書集成. Tokyo: Kan-Gi bunka kenkyūkai, 1959-1964.

Yasui Kōzan 安居香山 and Nakamura Shōhachi 中村璋八, eds. Jūshū isho shūsei 重修 緯書集成. Tokyo: Meitoku, 1971-1992.

Yiwei bazhong 易緯八種. In Sibu jiyao 四部集要.

Yuhanshan fang ji yishu 玉函山房輯佚書. Compiled by Ma Guohan 馬國翰. In Siku quanshu.

Yuhanshan fang ji yishu xubian 玉函山房輯佚書續編. Compiled by Wang Renjun 王仁俊. Shanghai: Shanghai guji chubanshe, 1989.

Zeng Dexiong 曾德雄. “Chenwei de jinjue yu jiyi” 讖緯的禁絕與輯佚. Yunmeng xuekan 雲夢學刊 32, no. 5 (2011): 58-66.

Zeng Dexiong 曾德雄. “Chenwei zhong de Kongzi” 讖緯中的孔子. Renwen zazhi 人文 雜誌, 2006 no.1, 98-105. 
Zhao Lu. In Pursuit of the Great Peace: Han Dynasty Classicism and the Making of Early Medieval Literati Culture. Albany: State University of New York Press, 2019.

Zhong Zhaopeng 鍾肇鵬. Chenwei lunlüe 䜟緯論略. Shenyang: Liaoning jiaoyu chubanshe, 1991.

Zhong Zhaopeng 鍾肇鵬 and Xiao Wenyu 蕭文郁. Qiwei 七緯. Beijing: Zhonghua shuju, 2012.

Zhou Yi zhengyi 周易正義. Edited by Wang Bi 王怩. In Shisan jing zhushu十三經注疏, edited by Ruan Yuan 阮元. Beijing: Zhonghua shuju, 1980.

Zhu Yizun 朱彝尊.Jingyi kao 經義考. In Siku quanshu. 